\title{
Mr. Bai and Mr. Qian Earn Their Living: Considering Two Handwritten Notebooks of Matching Couplets from China in the Late Qing and Early Republic
} 老白老錢寫對聯兒

\section{Introduction}

This chapter explores two chaoben that I bought in China in the spring of 2012. They were written between the end of the Qing dynasty, around 1880, and the early years of the Republic, about 1913. They were both written by literate men whose daily life was very close to the common people in terms of their life expectations and their modest incomes. The men, who had received some formal education and had the ability to read and to write, took advantage of those abilities to earn income by preparing couplets of congratulatory poems that were, and still are, a big part of the social and celebratory life of the Chinese. By attempting to draw inferences and make logical assumptions from the information in these two chaoben and the manner in which the information was presented, I suggest the ways in which they can reveal something about the lives, the worldview, and the economic standing of both men. By looking carefully at the contents of what they wrote, we see that these chaoben can also be used to reconstruct something about the communities in which both men lived and worked.

The bulk of the content in both chaoben is matching couplets. Many literate men in this period could regularly earn extra income by offering to write matching couplets, celebratory rhyming phrases that were demanded on many social occasions, such as New Year festivities and weddings. Many handwritten booklets containing sample phrases are available in the used book markets in China. The volume of chaoben available in markets attests to the popularity of matching couplets and the ubiquity with which literate men turned to this custom as a way to earn income. In addition to introducing matching couplets, this chapter takes us to the village and city streets where ordinary people lived and worked. Rhyming couplets captured the values and the images of the common people of that era and we can use them to symbolically construct the world as they knew it and as they thought it should be.

(C) RONALD SULESKI, 2018 | DOI:10.1163/9789004361034_009

This is an open access chapter distributed under the terms of the prevailing CC-BY-NC License at the time of publication. 


\section{Mr. Bai}

Once, while visiting China, I came to know a man whom I named Mr. Bai 白, a common Chinese surname. Bai means "white" or "blank," which seems appropriate. I did not meet him in person, because he lived in China in the early years of the twentieth century and has long since passed away, but I bought a chaoben he had kept for himself, and by reading it I came to know many things about his life.

I bought his chaoben at the Panjiayuan antiques market in Beijing in May 2012. Because of where I bought it, I assume that Mr. Bai lived in North China, since most of the handwritten materials collected by dealers and sold at Panjiayuan come from North or Northeast China. Mr. Bai used browned and unbleached inexpensive handmade paper, and he wrote using a Chinese-style writing brush. From his acceptable but mediocre calligraphy, I assume that he received some formal education but did not complete his education and most likely never received even the lowest-level degree awarded by the county officials where he lived. He was literate and could write many characters, but at the same time he was not sure how to correctly write all the characters he wanted to use, so he sometimes wrote out commonly used characters in the chaoben for his own reference. His text, in other words, contained notes to himself in the margins that used basic characters and phrases that he wanted to remember correctly. One example was: fu, lu, shou, shanxing 福祿壽, 三星 [blessings, advancement, long life, the three stars] on page 22. The pages were formed by a larger sheet of paper being folded to make two pages, with the open ends bound along the right margin. I call this work Mr. Bai's Notebook [Bai xiansheng zhi chaoben 白先生之抄本], whose final size after each sheet of paper had been folded in half is 6 in $\times 7^{1 / 4}$ in $(15.2 \mathrm{~cm} \times 18.4 \mathrm{~cm}) .{ }^{1}$

Mr. Bai evidently decided that one way he could earn a living was by working as an elementary-school teacher or tutor in the village or small town where he lived. The world in which Mr. Bai lived had been shaken by a drastic reform carried out in 1905 by the Qing government. That reform abolished the classical education system, most likely the system under which Mr. Bai had begun his studies, and declared that all the standard texts that had been used for centuries to educate students were no longer accepted as the core texts for the educational curriculum. ${ }^{2}$ Instead, a new system based on the educational

1 See Suleski (Xue Long 薛龍), “Wan-Qing Minguo shiqide minjian chaoben.” At the time this article was published, I had not yet discovered Mr. Bai's chaoben.

2 The classical style of essay writing, called wenyanwen 文言文 [literary style], remained 
models used in the West and in Japan, which used graded textbooks on geography, mathematics, world history, civics, and so on, was adopted, including a system of schools organized around elementary education in six grades and higher education based on a middle school and upper-middle school pattern. It seems likely that this unexpected change interrupted Mr. Bai's education. He could easily have felt unprepared to enter the new system so suddenly imposed on the country, and he was lost as to how best to proceed with his own studies. $^{3}$

Although his own education and calligraphic ability were limited, compared to most people Mr. Bai would have been considered educated because he could read and write, and in the countryside where he lived, he could still be a teacher or a tutor for young students who sought to acquire a basic ability to read and write even if their parents did not have the money to enroll them in a modernstyle local school. In the society in which he lived, which, as discussed earlier, had a literacy rate of perhaps 30 percent, Mr. Bai's ability to read and write already exceeded that of the majority of the population. ${ }^{4}$

popular, however, and continued to have social and economic relevance. Mr. Bai's writing followed a version of the classical style of prose. It was the style of writing he was teaching to his students, as later pages in his notebook reveal.

3 The impact of these educational reforms is discussed in Elizabeth R. Vanderven, A School in Every Village: Educational Reform in a Northeast China County, 1904-1931 (Vancouver: UBC Press, 2012). See also Bastid, Educational Reform in Early Twentieth-Century China. Many communities in China began to establish new-style schools earlier than 1905; see Situ Xing 司徒星, Kaiping xianzhi 開平縣誌 [Gazetteerfor Kaiping County], 2 vols. (Beijing: Zhonghua shuju, 2002), esp. the section on Kaiping history from 1573 to 1999. For an excellent narrative on the impact of educational changes on the life of an individual, see Henrietta Harrison, The Man Awakened from Dreams: One Man's Life in a North China Village, 1857-1942 (Redwood City, CA: Stanford University Press, 2005). Comments on the lingering effects of the 1905 educational reforms even into the 1930s are made in Lin Chih-hung (Lin Zhihong) 林志宏, "Shibianxia de shibian: Keju feichu he zhishi jieceng de dingwei (190os-1930s) 世變下的士 變：科舉廢除和知識階層的定位 [Change for Scholars in a World of Change: Abolishing the Higher Examination and the Position of the Intelligentsia]," in Shenfen, wenhua yu quanli: Shizu yanjiu xintan 身份文化與權力：士族研究新探 [Identity, Culture, and Influence: New Research on the Scholarly Class], ed. Gan Huaizhen 甘懷真 (Taipei: National Taiwan University Press, 2012), 387-424.

4 Some villagers in South China in the area of present-day Hong Kong report that in 1911 (when Mr. Bai was active), 55 percent to 67 percent of adult men in rural villages considered themselves literate. See Hase, Custom, Land and Livelihood in Rural South China, 18. My suggestion is that since these men could write their names and a number of characters and could make out basic written texts, they believed they possessed adequate literacy for their needs. I think this was likely true for many rural dwellers in China. It is not evident 
Mr. Bai first wrote down a number of well-known poems (pp. 1-9) taken from the standard collection Tangshi sanbaishou 唐詩三百首 [Three Hundred Poems of the Tang Dynasty]. He knew that if his pupils could read and recite some of these poems, their parents and relatives would be pleased with Mr. Bai's teaching. The poems also show the continued respect given to classical forms of education in China even after the educational reforms declared them obsolete. $^{5}$

He followed this section by writing in his notebook a story that he could teach to his students. It would give them some historical knowledge, since he could explain the background of the story. He wrote (p. 9) the story "Taigong diaoyu 太公釣魚 [Taigong Goes Fishing].” According to the story surrounding this tale, the historical background Mr. Bai would no doubt explain to his students was that in ancient days an official known as Jiang Taigong 姜太公 had helped the king of the Zhou 周 dynasty (1046-256 BCE) establish his kingdom. Finally, at the age of eighty, Taigong was named prime minister, an award for his long-lasting loyalty. It is said that when he went fishing, unlike other people, who used a curved hook on which to ensnare the fish, Taigong used a simple straight hook. When people pointed out to him that a straight hook would not catch many fish, Taigong replied that, when the fish he was trying to catch swam by, it would bite the lure on the hook, and Taigong would catch it. This story is still used in modern Chinese and Korean classes to teach children the virtue of patience, the idea that you cannot achieve your goal until the time is ripe. At the same time, the tale conveys an underlying sense of optimism, that persistence and hope will be rewarded. I like to think that Mr. Bai selected this story to teach his students because it reflected Mr. Bai's own personal sense of optimism and perseverance.

whether these men could or could not read a book or a newspaper with full comprehension. Even if they could read, they might not be able to write. Still, if they could meet all their basic needs using written material as necessary, we should call them literate. Many land contracts are presented in Hase's book in a form of bureaucratic Chinese based on the classical style. If the villagers could read and understand those contracts, I would label them literate. For an excellent collection of various types of land contracts, including photographs and complete texts, see Zhang Deyi 長德義 et al., Zhongguo lidai tudi qizheng 中國歷代土 地契證 [Chinese Historical Land Documents] (Baoding: Hebei daxue chubanshe, 2009).

5 This collection of poems from the Tang dynasty (618-907) was compiled around 1763 by the Qing scholar Sun Zhu 孫洙 (1722-1778). At the time Mr. Bai was teaching students in the early 19oos, it was widely used in schools and academies. The collection continued to grow in popularity throughout the twentieth century. Copies of this collection are still widely available in Chinese communities. 


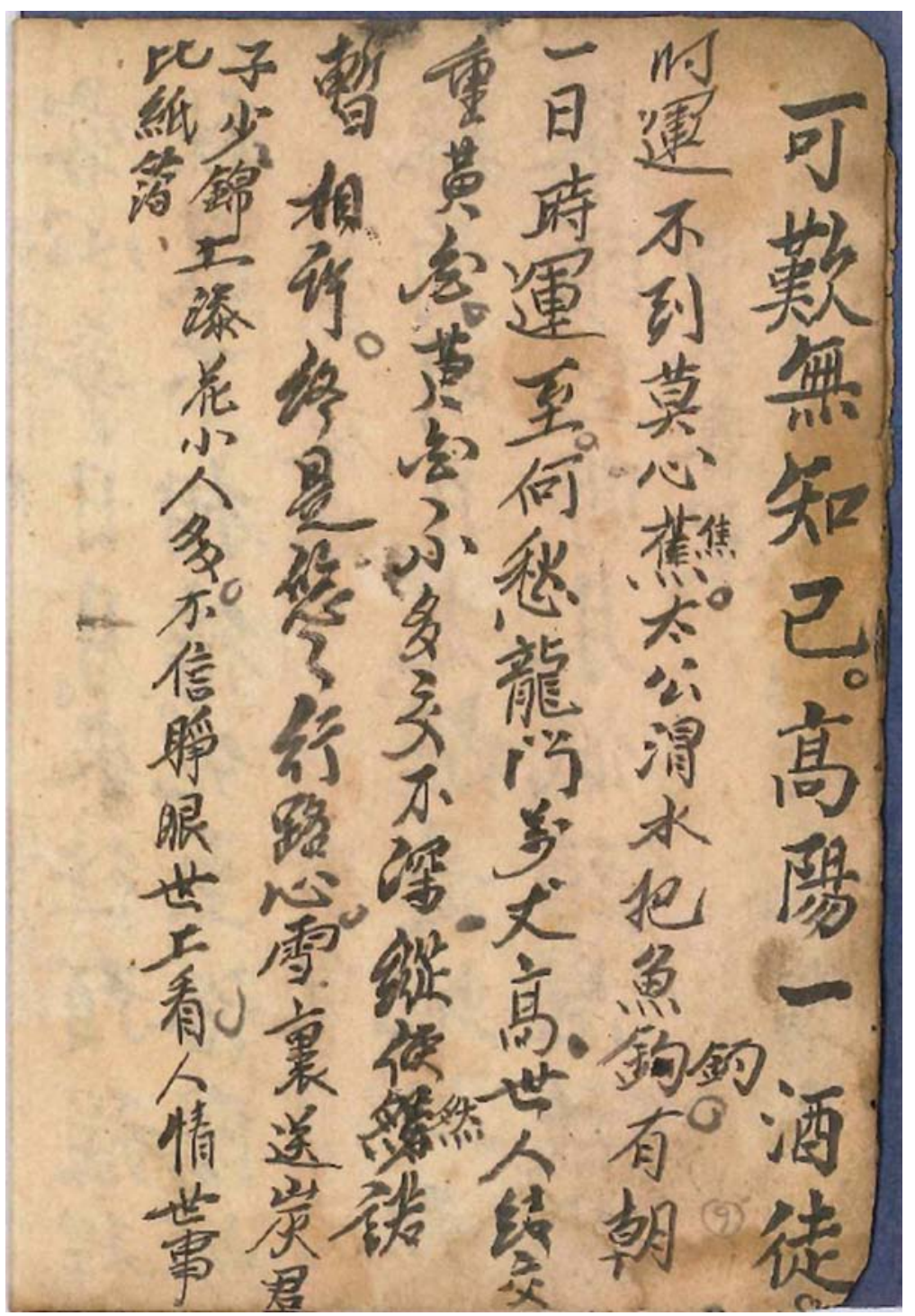

FIGURE 7.1

Mr. Bai's Notebook [Bai xiansheng zhi chaoben 白先生之抄本], Page 9, The Story of Taigong 太公. Here Mr. Bai was teaching his students the story of Taigong, an official in ancient China who has become a deity. Taigong was best known for fishing with a straight hook. When asked why, he replied, "When the fish who wants to be caught comes by, I will catch him." Mr. Bai added his own comments to the story in order to prepare his students for the real world of adult life. He said in part: "People make friendships, and often money is involved. But when you don't have much money, you won't have many friends" [Shiren jiejiao zhonghuangjin, Huangjin buduo jiaobushen 世人结交 重黄金, 黄金不多交不深].

PHOTO BY AUTHOR 
According to other popular versions of the story, Taigong came to the attention of the Zhou dynasty King Wu 武 (r. 1046-1043 BCE) and his father because of Taigong's practice of fishing with an unbent hook. When asked why, Taigong replied, "When the fish who wants to be caught comes by, I will catch him." As mentioned above, this was seen as a thoughtful strategy in governance and military matters as well as an example of optimism and perseverance. Another philosophical lesson was that a person might have an implicit purpose in his actions other than the obvious ones, and we must look beneath the surface when trying to understand the motivations of others. ${ }^{6}$

The story as Mr. Bai copied it continued with some of his own commentary:

The time of good fortune will no doubt arrive, so there is no need to worry. Taigong went fishing in the Wei River. One morning his luck arrived, so why worry even if the Dragon Gate appears to be a thousand meters high?

Shiyunbudao, moxinjiao. Taigong weishui, bayudiao. Youzhaoyiri, shiyunzhi, heqiulongmen, wangegao.

時運不到, 莫心焦。太公渭水, 把魚釣. 有朝一日, 時運至, 何愁龍門, 萬戈高.

Mr. Bai's simple classical style was close to vernacular speech, and it rhymed, so it could be more easily memorized.

In continuing his short essay, Mr. Bai talked about "affairs of the world" [shishi 世事]. In that section, he wanted to warn his students to be cautious as they dealt with others. He indicated that people had self-serving natures and could not be counted on in times of trouble. The point was that decent people were few, but petty people were numerous [junzi shao, xiaoren duo 君子少, 小人多]. This may have reflected another side of Mr. Bai's personality, in which he felt some bitterness, perhaps because his own education and prospects for

6 The story is paraphrased here in both versions given, neither of which is a literal translation of Mr. Bai's simplified classical style. On the story of "Taigong Goes Fishing" (here titled Jiang Taigong diaoyu 姜太公釣魚), see Zhongguo lishi wenhua changshi tongdian 中國 歷史文化常識統典 [Encyclopedia of Popular Knowledge on Chinese History and Culture] (Kunming: Yunnan jiaoyu chubanshe, 2010), 124. Many lessons can be drawn from this story. For example, another lesson is the that some people are willing to be caught. Further, my partner, who was raised in South Korea, said some Koreans joke that the lesson of this story can be used as an excuse for doing nothing (Jonghyun Lee, personal communication, July 2012). 


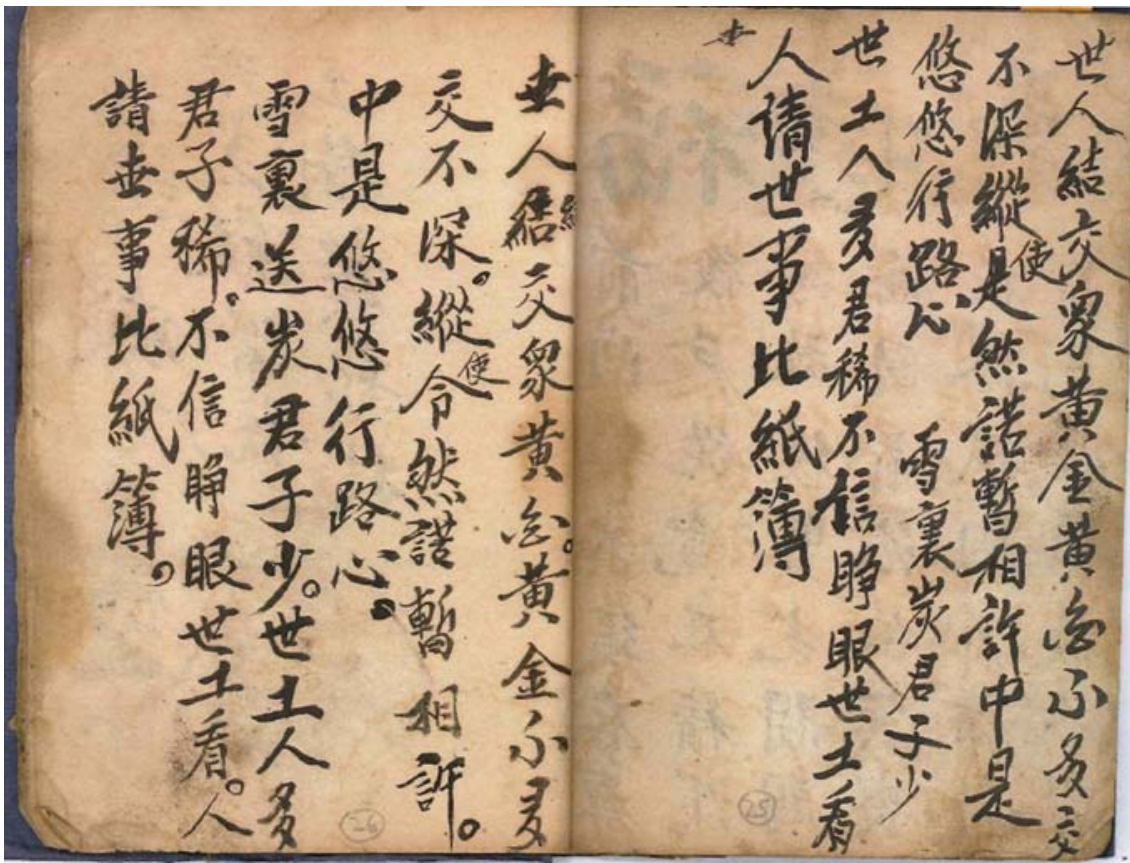

FIGURE 7.2

Mr. Bai's Notebook [Bai xiansheng zhi chaoben 白先生之抄本], Pages 25 and 26, Student Calligraphy. Mr. Bai asked two of his students to copy the Taigong commentary. They did so on these two pages, using their still-developing calligraphic skills and occasionally missing a phrase or word.

РНОTO BY AUTHOR

the future had been interrupted. He was also giving his students a lesson in applying common sense and telling them to avoid being misled as they entered the adult world. Because he was a member of the common people, all of $\mathrm{Mr}$. Bai's actions, I argue, were aimed at the realistic application of his skills and his lessons to the real world of people and commerce and work.

The story of Taigong is followed by:

People make friends, and often money is involved. But if you don't have much money, you won't have many friends. This might cause you to worry, and for a while you will hold on to the friend, but in the end people part ways. Very few people will send you coal during the snows of winter, and even worse [lit. "to add flowers to the brocade"] many petty people will surround you. If you don't believe me, just look at the ways of the world. Human feelings in this world are as thin as paper. 
Shirenjiejiao zhonghuangjin, huangjinbuduo, jiaobushen. Zongshi rannuo, zanxiangxu, zhongshiyouyou, xingluxin.Xuelisongtan, junzishao, jinshang tanhua, xiaorenduo. Buxin zhenyan, shishangkan, renqing shishi, bizhibo.

\section{世人结交重黄金, 黄金不多交不深。縱使然諾暫相許, 终是悠悠行路 心。雪裏送炭君子少, 錦上添花小人多。不信睁眼世上看, 人情世事 比纸薄. (p. 9$)^{7}$}

Mr. Bai taught this story to some of his students. He then asked two of them to copy the final portion of the essay in the pages of his notebook. They did so, occasionally omitting or miswriting a character, but Mr. Bai kept their assignment in his notebook (pp. 25 and 26). I wonder if one of those young students was named Jiang Wen 姜文, because that student—in not very good handwriting - twice wrote his name later in the notebook (on pp. 41 and 43). Another person at a beginning level of calligraphy, possibly another student of Mr. Bai, also wrote his name in the notebook: Yang Keming 楊克明 (p. 43). These are the only two names of living people who appear in the notebook. I wonder if Mr. Bai's surname was actually Jiang 姜. Was the boy Jiang Wen 姜文 his son? Was this the reason he selected the story of "Taigong Goes Fishing," since Taigong's surname was also Jiang? ${ }^{8}$

Another likely way for Mr. Bai to earn an income was to offer to write various congratulatory and ceremonial couplets for people. Although the majority of the Chinese population could not fully read or write such couplets, it was considered necessary to have these paper banners hung at all important occasions. They are often written on red paper, with the first banner hung on the viewer's

7 Mr. Bai's version is based on a Tang poem composed by Zhang Wei 張謂 (d. 777?), which had the generic title "Tichang anbi zhuren 提倡安壁主人 [Questions for the Master of the An Wall]." The first two lines of Mr. Bai's version are taken from this poem, and they rhyme. The phrase "to give added luster" [jinshang tanhua 錦上添花], which I have sarcastically translated as "even worse," is a well-known Chinese idiom. See Hanyu chengyu cidian 漢語 成語詞典 [Dictionary of Chinese Idioms] (Shanghai: Shanghai jiaoyu chubanshe, 1987), 306.

8 Taigong is the honorific title given to Jiang Shang 姜尚. Some sources say that, as a god, he grants titles to Daoist deities; some sources suggest placing his tablet on the roof beam as a new house is being constructed to ensure blessings; other sources say his tablet should be placed in the marriage chamber of newlyweds because he will represent the personality of the husband, which should be one of patience and perseverance. On Jiang Taigong 姜太 公, see Yi Baoqun 奕保群, ed., Zhongguo shenguai dacidian 中國神怪大辭典 [Dictionary of Chinese Spirits and Ghosts] (Beijing: Renmin chubanshe, 2009), 221-222. See also Shi Xiaojin 史孝進 et al., ed., Daojiaofengsu tan 道教風俗談 [Talking about Daoist Customs] (Shanghai: Shanghai cishu chubanshe, 2003), 25-27. 


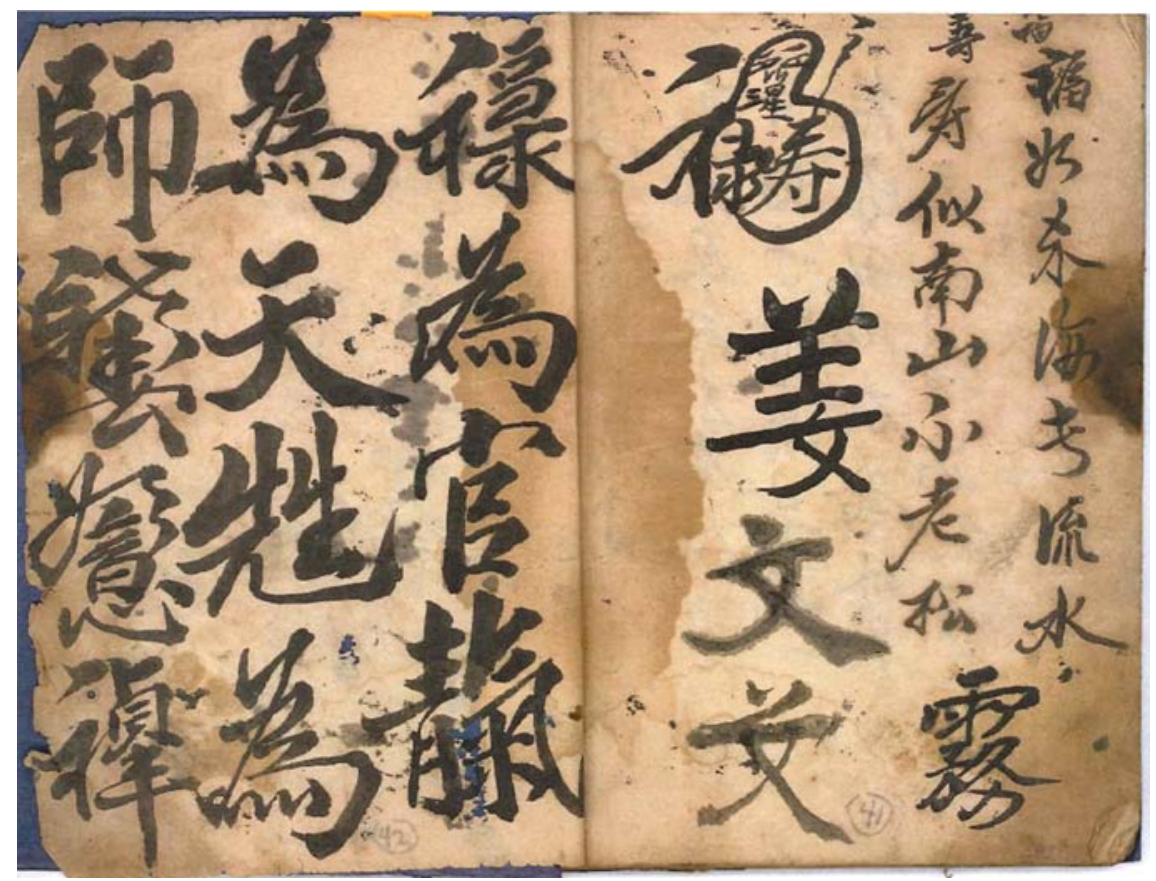

FIGURE 7.3

Mr. Bai's Notebook [Bai xiansheng zhi chaoben 白先生之抄本], Pages 41 and 42, A Boy's Name. This messy writing, which is characteristic of the chaoben prepared by Mr. Bai, includes the name of a boy, Jiang Wen 姜文. It appears to have been written by a child—was this the name of one of his students or the name of his son?

Рното BY AUTHOR

right while the matching second line is hung on the viewer's left. They are considered matching pairs because the phrases used in the first line complement those used in the second line. Welcoming the lunar New Year is the most festive time of the year in China, and it continues to be the general practice that a matching couplet written on red paper is hung on either side of the front gate. When written to celebrate the New Year, these are called "spring couplets" (chunlia'r 春聯兒 in the northern dialect). They express sentiments having to do with new growth, with welcoming, and with flowering and abundance. ${ }^{9}$

9 Hanging red New Year's couplets on the sides of the gate or front door continues to be widely practiced in China and Chinese communities worldwide. Modern almanacs usually contain sample texts for couplets. In more traditional times, people could hang couplets to commemorate important family events, such as a wedding, the birth of a son, or the birthday of an elder. But in contemporary China, these occasions are usually not noted by a new couplet at the gate, possibly with the exception of weddings, when hanging new couplets painted on 


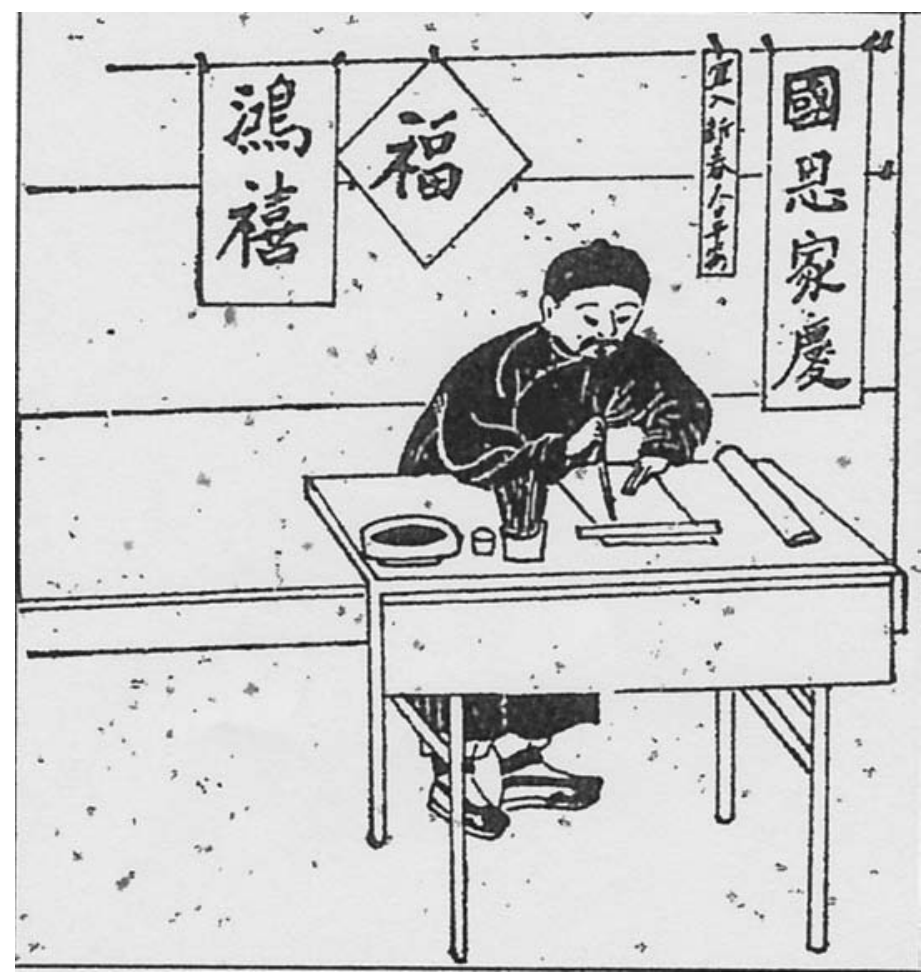

FIGURE 7.4

Mr. Bai Writing Celebratory Scrolls. Writing matching poetic couplets [duilian 對聯] was a sure way for Mr. Baito earn money. The new year was an especially busy time, because every house wanted poetic phrases written on red paper to paste at their front gate, and weddings were other occasions when it was necessary to hang banners on red paper.

THIS IMAGE IS TAKEN FROM SHI XIAOJIN 史孝進 ET AL., ED., DAOJIAO FENGSU TAN 道教 風俗談 [TALKING ABOUT DAOIST CUSTOMS] (SHANGHAI: SHANGHAI CISHU CHUBANSHE, 2003), 55

bright red paper is still favored. Couplets for the New Year outnumber those for any other occasion. Indeed, many modern almanacs only contain samples for the New Year, weddings, and death. For an example, see Zhang Ming 張明, ed., Zhonghua minsu wannianli 中華民 俗萬年曆 [Chinese Popular Customs, Ten-Thousand-Year Calendar] (Zhongzhou:Zhongzhou guji chubanshe, 2005), 383-404. The important role of these couplets at the New Year is also explained in H.Y. Lowe 盧興源, The Adventures of Wu: The Life Cycle of a Peking Man, trans. Derk Bodde (Princeton: Princeton University Press, 1983), 2: 140-147. On preparing matching couplets for the New Year, see Tun Li-ch'en 敦禮臣, Annual Customs and Festivals in Peking, trans. Derk Bodde (Hong Kong: Hong Kong University Press, 1965), 98-100. This book is a translation of Yanjing suishiji 燕京嵗時記 [Annual Customs of Yanjing], originally published about 1902 . 
Mr. Bai knew he would receive many requests to prepare New Year couplets to be hung on the front gate. In his chaoben, he called this category simply mentou 門頭 [front gates]. He devoted several pages (pp. 12-24) to forty-eight examples of New Year couplets that he could offer his customers, in four-, five-, and seven-word-per-line versions. ${ }^{10}$ For example, a couplet to welcome the New Year, one that Mr. Bai particularly liked as indicated by his circling it in red in his notebook, read: "The wind arises and the flowers sway, Spring arrives and the birds can fly” [Fenglai huaziwu; Chunru niaonengfei 風來花自舞; 春入鳥能 飛; p. 18]. In this couplet, the first phrase in the first line, "wind arises" [ fenglai 風來], is matched by the first phrase in the second line, "spring arrives" [ chunru 春入]. The next phrase in the first line contains an adverb-noun phrase, "and the flowers sway" [huaziwu 花自舞], matched by the phrase in the second line, "the birds can fly" [niao neng fei 鳥能飛]. Matching couplets of this sort are appreciated by the Chinese even today. Mr. Bai did not compose any of the couplets he sold or the texts he taught to his students. He copied them from other texts, either from printed books or chaoben of other teachers like himself. Many of the phrases in the couplets were taken from classical poetry. ${ }^{11}$

Another couplet that Mr. Bai especially liked under the category of spring couplets, and probably thought would be popular with his customers, read: "In the spring, falling rains open the early flowers; In the autumn, under clear skies the last leaves float down" [Chunqian, youyu, huakaizao; qiuhou, wushuang, yeluochi 春前有雨花開早; 秋後無霜葉落遲; p. 12]. This couplet speaks to the inevitability of spring's coming and going, a process that takes place "sooner or later" [chizao 遲早], which are the last characters of each line, completing the complementary matching of both phrases. ${ }^{12}$

10 As do modern almanacs. However, see Zhang, Zhonghua minsu wannianli, which gives samples texts in four-, five-, six-, seven-, and eight-word versions on pp. 389-398. Comments on how these have been used in rural villages are in James Hayes, "Specialists and Written Materials in the Village World," in Popular Culture in Late Imperial China, ed. David Johnson et al. (Berkeley: University of California Press, 1985), esp. 83-84.

11 Most of the phrases used in the matching couplets come from classical poetry. The poetic phrase used here comes from a Tang-dynasty poem by Song Zhiwen 宋之問 (656-712), “Chunri furongyuan shiyan yingzhi 春日芙蓉園侍宴應制 [Writing Poems in the Lotus Garden]," in Quan Tang shi 全唐詩 [Complete Poems of the Tang], juan 52:2.

The Baidu website http://zhidao.baidu.com/question/595719417.html, accessed March 2014 and August 2017, suggests that portions of this couplet, specifically Chunqian, youyu, huakaizao 春前有雨花開早 was part of a widely circulated saying [yanyu 諺語] in North China. It also suggests the original locus classicus for the phrase was a Han-dynasty lyric poem [yuefu 樂府] “Kongque dongnanfei 孔雀東南飛 [Peacocks Fly Southeast].” We should not assume that Mr. Bai consulted literary texts in order to come up with these 
In selecting the categories of couplets that he would offer to write for people, Mr. Bai must have thought about the community in which he lived, determined which members of that community might ask him to write a couplet, and thought about the occasions when they were likely to ask for his help. Thus the section of his notebook devoted to sample couplets for his reference actually reveals much about Mr. Bai's village or his immediate community, the life events that were important to them, as well as the types of people who lived in his village and were likely to request a couplet from him. (The couplets are written on pages 10-40, meaning that the majority of pages in this notebook are devoted to texts for couplets.)

As seen below in more detail, Mr. Bai prepared multiple sample couplet verses, divided into categories. We can assume that the categories in which Mr. Bai had a large number of readymade samples were those from which he assumed a larger number of customers would order a couplet. Conversely, some categories had only one or two sample texts, so we can assume that Mr. Bai did not count among his likely customers people associated with those categories of activities or needs. By keeping in mind the number of sample couplets in each category, we can further predict the types of people likely to be ordering couplets from Mr. Bai. The same holds true for Mr. Qian, discussed below.

We can assume that Mr. Bai tutored students, and he must have expected that the parents of these students were likely to ask him for a couplet at some point, to celebrate a holiday or to announce the fact that their child (probably a son) was a student. Mr. Bai wrote out twelve sample couplets as general felicitations (pp. 13-16 and 39-40). Because this notebook shows that Mr. Bai's calligraphy was not especially polished or refined, we can surmise that the people who lived in Mr. Bai's community were probably not wealthy and had little formal education. Even so, the couplet texts that Mr. Bai selected to offer his potential customers expressed the values of the educated, literate, Confucian elite. Naturally, one would want to present to the outside world an image of a properly ordered family that endorsed the most established (and conventional) cultural values. This point becomes clear in the discussion that follows.

Always expressing a positive idea, some of his samples honored the practice of reading or reciting texts [dushu 讀書, pp. 14 and ${ }_{15}$, five examples] and the

lines, because none of his customers expected him to compose original poetry for a scroll but, rather, all assumed that he copied phrases from widely circulated books, as did other writers of celebratory scrolls at the time and today. I thank Zhou Donghua 周東華 of Hangzhou Normal University [Hangzhou shifan daxue 杭州師範大學] for good suggestions as I translated some of these couplets. 


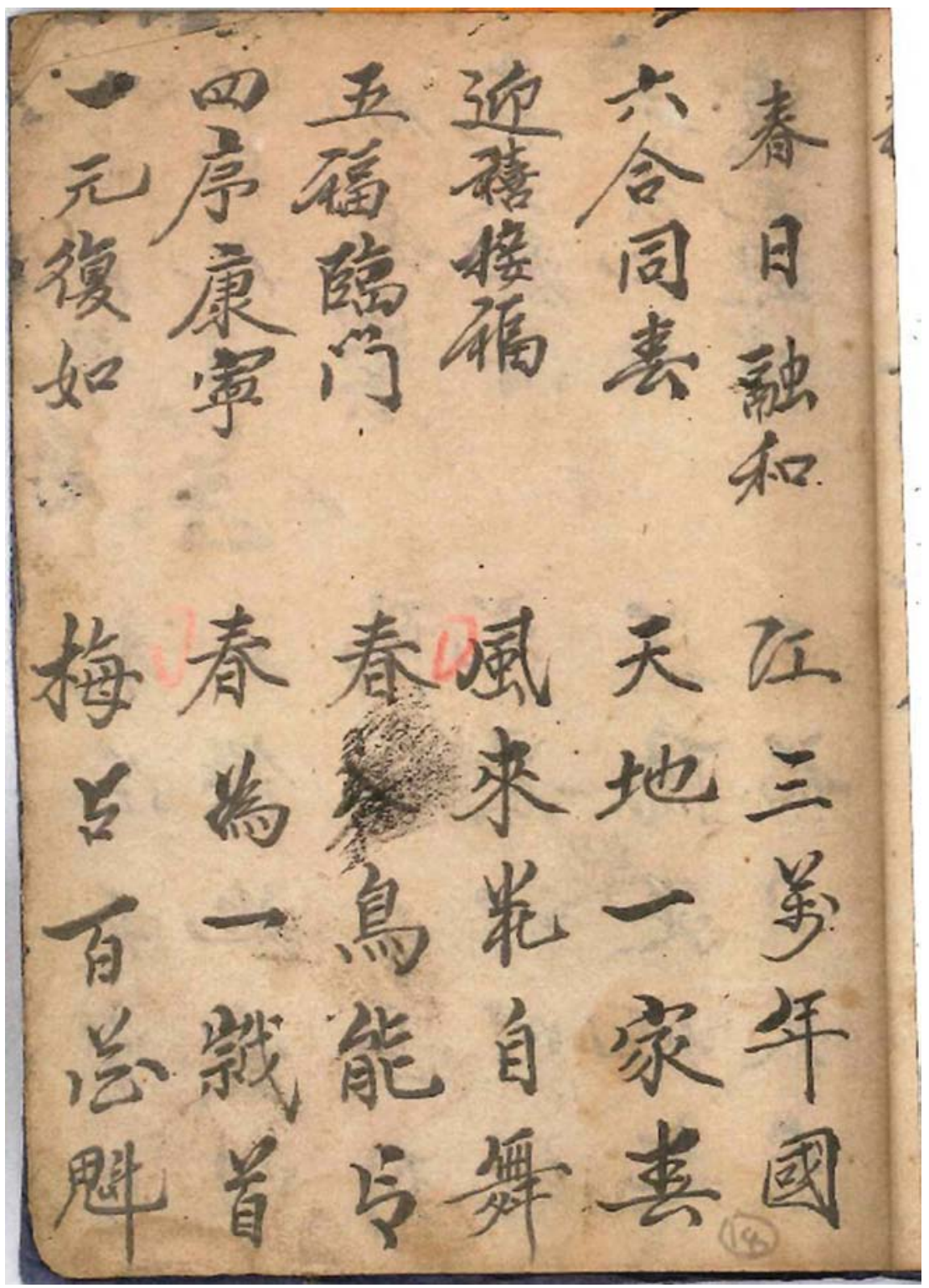

FIGURE 7.5

Mr. Bai's Notebook [Bai xiansheng zhi chaoben 白先生之抄本], Page 18, An Ode to Spring. This page shows a duilian that Mr. Bai especially liked, as indicated by the red circles he added at the beginning of the phrase, in the third and fourth vertical lines in the bottom half of the page. It reads: "The wind arises and the flowers sway, Spring arrives and the birds can fly" [Fenglai huaziwu; chunru niaonengfei. 風來花自舞; 春入鳥能飛]. Spring [chun 春] indicates the new year, which, according to the lunar calendar, arrives in late January or early February.

PHOTO BY AUTHOR 


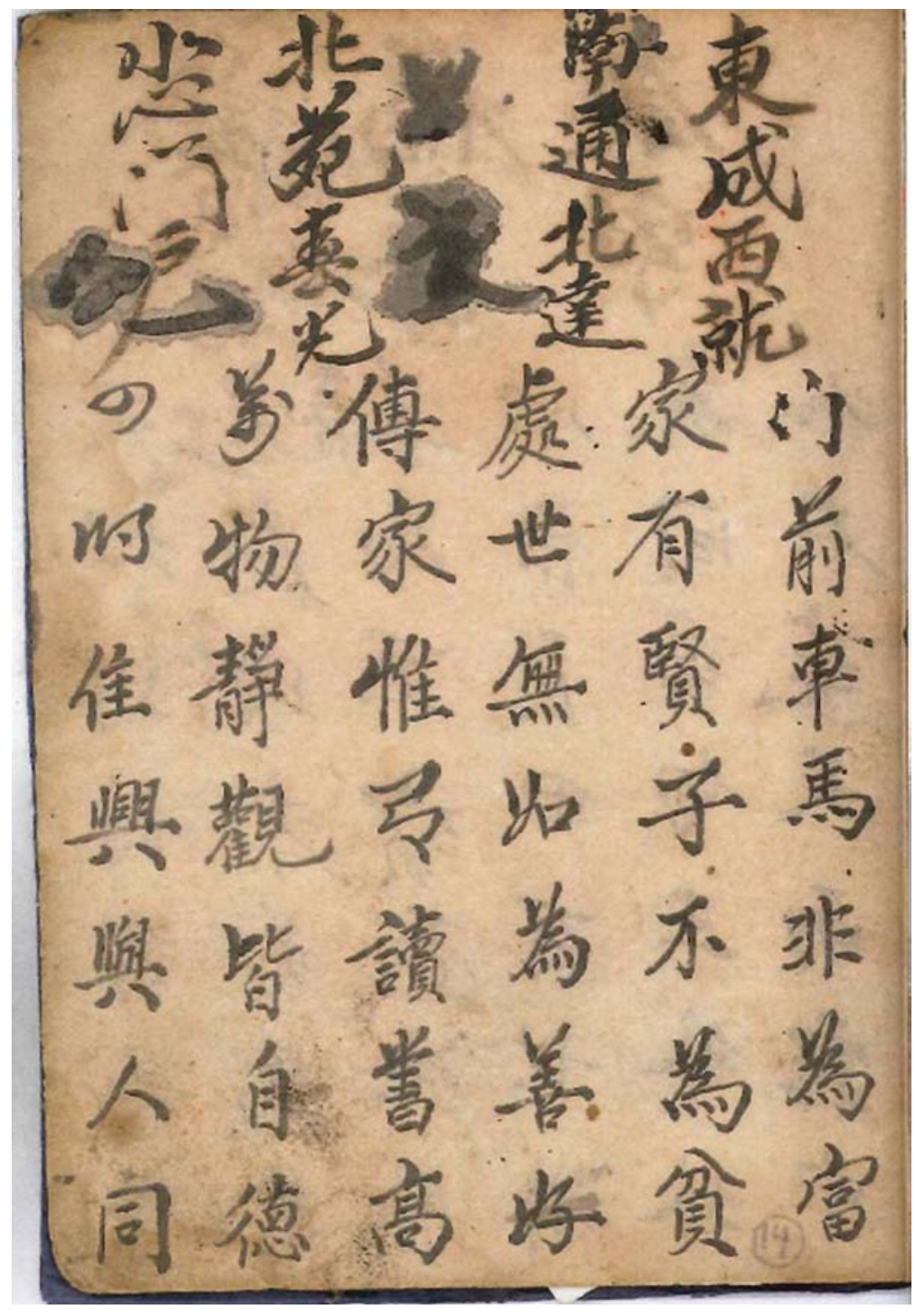

FIGURE 7.6

Mr. Bai's Notebook [Bai xiansheng zhi chaoben 白先生之抄本], Page 14, Expressing Acceptable Sentiments. On this page, Mr. Bai wrote sample verses that his customers could select to show their neighbors that they were a goodfamily, according to conventional Confucian morality. Mr. Bai wrote: "In front of the gate, having a horse and carriage does not indicate wealth; To have a worthy person in the family means it will never be poor" [Menqian chema feiweifu; jiayou xianzi buweipin 門前 車馬非為富 ; 家有賢子不為貧]. For poor families who could never afford a horse or carriage, this couplet expressed suitable and accepted sentiments about their righteous behavior. These are the first and second vertical lines in the bottom half of the page.

Pното BY AUTHOR 
place of poetry and writing [shishu 詩書]. He wrote: "In front of the gate, having a horse and carriage does not indicate wealth; To have a worthy person in the family, means it will never be poor" [Menqian chema feiweifu; Jiayou xianzi buweipin 門前車馬非為富; 家有賢子不為貧; p. 14]. This phrase could appeal to a family with a low income and perhaps a gate that was small and not imposing, but the family could claim it had a son, so its future was assured. A similar example was: "In the world, nothing is as fine as goodness; Within the family, the highest principle is to study" [Chushi wuru weishanhao; Chuanjia weiyin dushugao 處世無如為善好; 傳家惟引讀書高; p. 14]. With this phrase, a family could imply it was paying a teacher to tutor a son, even if its own home was not magnificent. Finally, a third example expressing the idea of a well-ordered family adhering to the prevalent Confucian-inspired values often repeated by elite members of society: "On heaven and earth, poems and books are the most important; Within the family, filial sons come first" [Tiandijian shishu zuigui; Jiatingneixiaodiweixian 天地間詩書最貴; 家庭內孝弟為先; p. 15].

I assume that Mr. Bai lived in a somewhat isolated rural area or felt part of a local community with few people of high social status. In other words, most people were members of the pingmin, as he himself was. Two of the couplets Mr. Bai wrote in his notebook seem to particularly reflect his own realistic and workaday view of life and the community in which he lived. He wrote "Donkeys and horses bring prosperity every year; Cattle and lambs increase daily" [Luoma niannianyi; Niuyang ririzeng 騾馬年年益; 牛羊日日增; p. 39]. Certainly, a household that relied on some animals for its income would appreciate a couplet such as this. Further, this is one of the indications that Mr. Bai's village was in North China or perhaps in Northeast China, which, unlike South China, had more open, flat land that could support pens and pasture to keep animals. Evidence that some businesses operated in Mr. Bai's vicinity is provided by his preparation of six examples of poems for commercial enterprises [shengyi tongyong 生意通用; pp. 36 and 37], but the texts were all of general nature and do not indicate what type of businesses might have ordered the scrolls.

Along the top margin of many pages, Mr. Bai wrote felicitous characters that people were likely to want written on festive occasions. Among these words (p. 15) were fu 福 [blessings], shou 壽 [long life], and kangning 康寧 [good health]. People might want them to be written on a piece of red paper to be placed horizontally [hengpi 横批] above the gate where the two celebratory scrolls were hung or on a diamond-shaped sheet of paper that could be pasted on the front gate itself or over a doorway. (Some of these often-used characters expressing good wishes are on pp. 15, 16, 22, and 24.) One characteristic of Mr. Bai's notebook is that many pages contain additional information that seems 


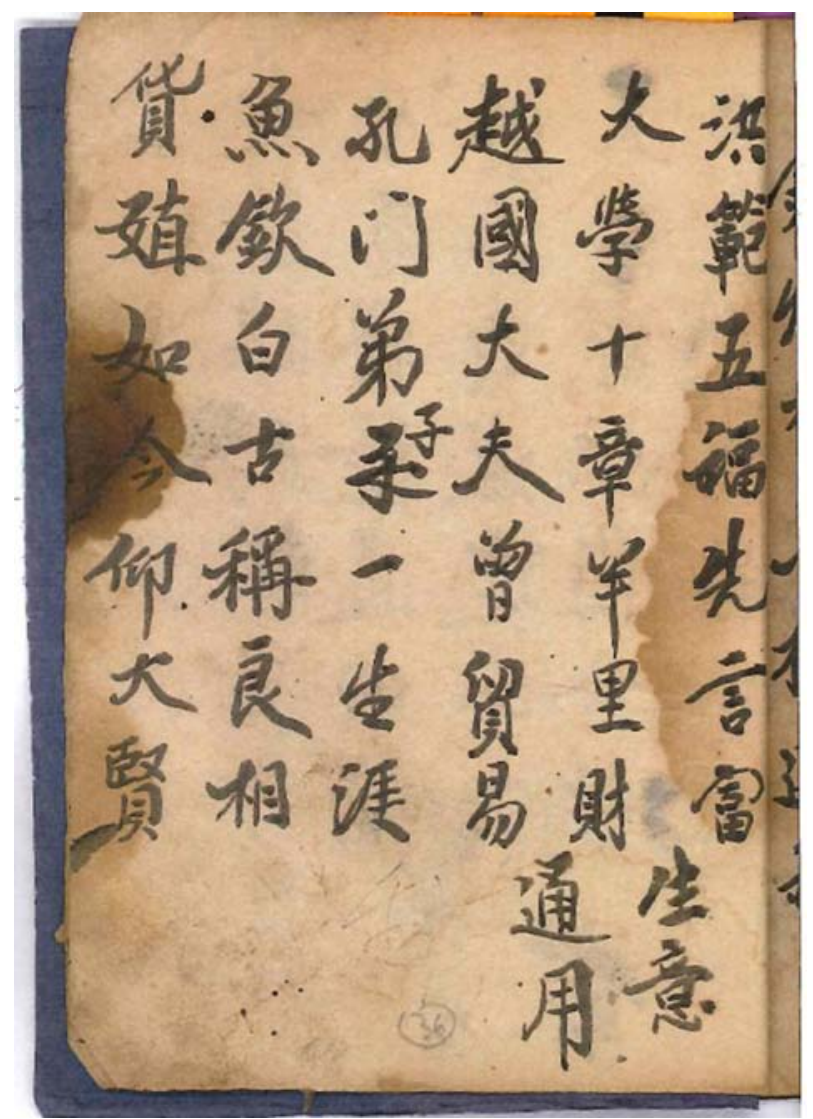

FIGURE 7.7

Mr. Bai's Notebook [Bai xiansheng zhi chaoben 白先生之抄本], Page 36, Scrolls for Merchants. It appears that Mr. Bai's community did not have many commercial establishments, and therefore he did not prepare many sample phrases for shop owners. The lack of businesses might indicate that Mr. Bai lived in a large village rather than in a small town. At the bottom of the page, Mr. Bai wrote “For use by all businesses" [Shengyi tongyong 生意通用] and then added three couplets (vertical lines 1 and 2, 3 and 4, and 5 and 6). The couplet on vertical lines 3 and 4 reads: "Gentlemen all over the country, increase commerce; Students from Confucian families, have excellent careers" [Yueguo dafu, cengmaoyi; Kongmen dizi, yishengya 越國大夫, 曾貿易; 孔門弟子, 一生涯]. Note that for the fifth character of the first line, Mr. Bai wrote ceng 曾 [at one point], but this is probably a mistake for zeng 增 [to increase]. Mr. Bai often made errors of this sort.

Pното BY AUTHOR

to have been added after the main text had been prepared. This indicates that his notebook was a working document used in the course of earning his living. It was not a notebook buried in a pile of other materials he had on his table but one that he consulted often and relied on to find the characters he needed in order to prepare matching couplets. 


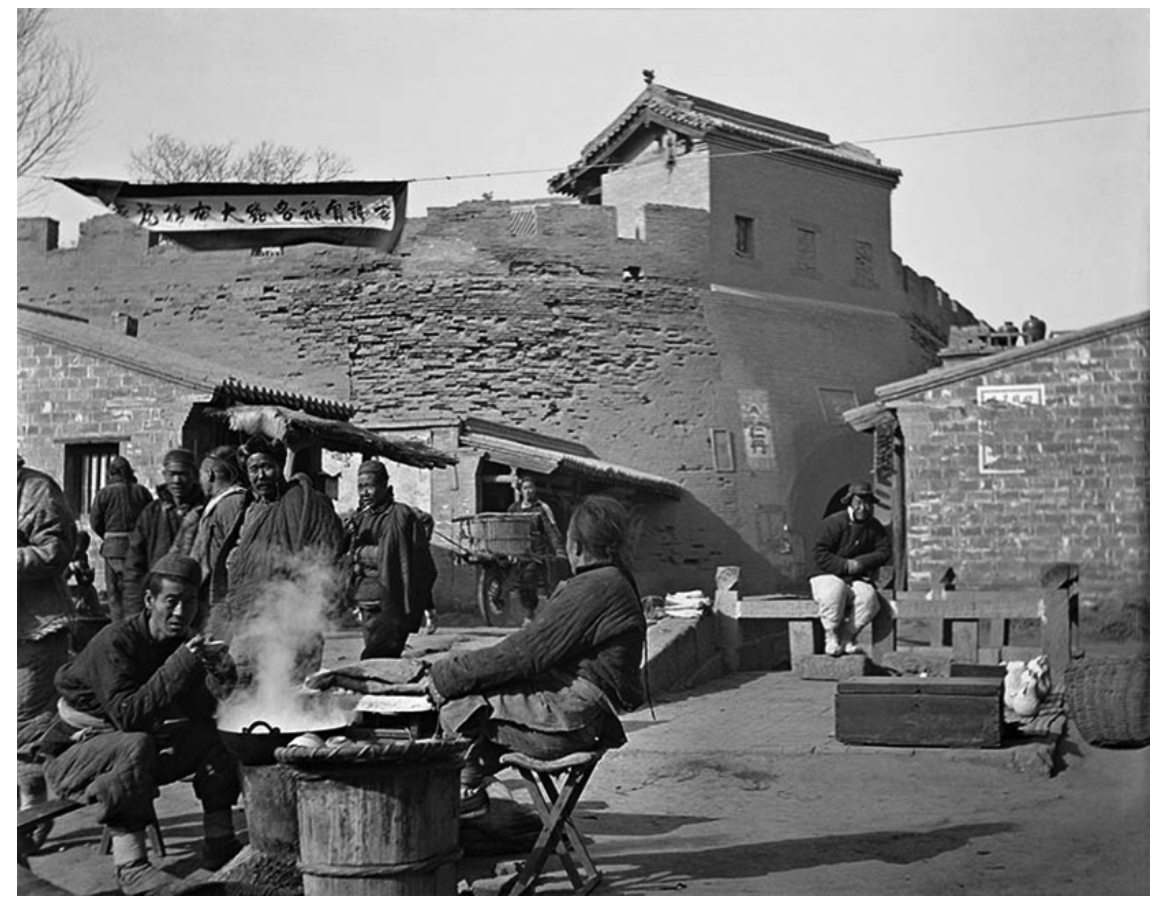

FIGURE 7.8

Laborers and Merchants in the Street. In this scene, a street vendor has set up shop to sell light meals. A group of laborers or merchants can be seen congregating. They are sitting near the town wall, and they have queues as required by the Manchus and wear padded clothing, which indicates the weather is cold.

PHOtO: SOUth GATE, tAigu 太谷, ShANXI 山西, 1916; PHOtO: William LEETE; RESTORATION AND PRINT (2) 215 WILLIAM MORSE. USED BY SPECIAL PERMISSION

These jottings, such as the extra characters that turn up on many pages, make the notebook look messy. Mr. Bai appears to be a man who was not very careful about neatness or precise order. In fact, he seems to have been an active person who quickly wrote down characters on whatever page was open at the time for reproduction later. Perhaps, at the time, he was talking to a customer or saw the character correctly written somewhere, so he quickly copied it into his booklet. I extrapolate from this, based purely on my imagination, an image of Mr. Bai as not elegantly dressed, wearing an ill-fitting, even a soiled, long gown and skullcap [guapimao 瓜皮冒] of the kind commonly still seen just after the fall of the Qing. The pages of his manuscript are worn, and the paper is often discolored from being handled by Mr. Bai as he consulted the book. The notebook he created is not neat, elegant, and precisely organized. It is, rather, a text quickly produced and then added to as new ideas came into Mr. Bai's head. 


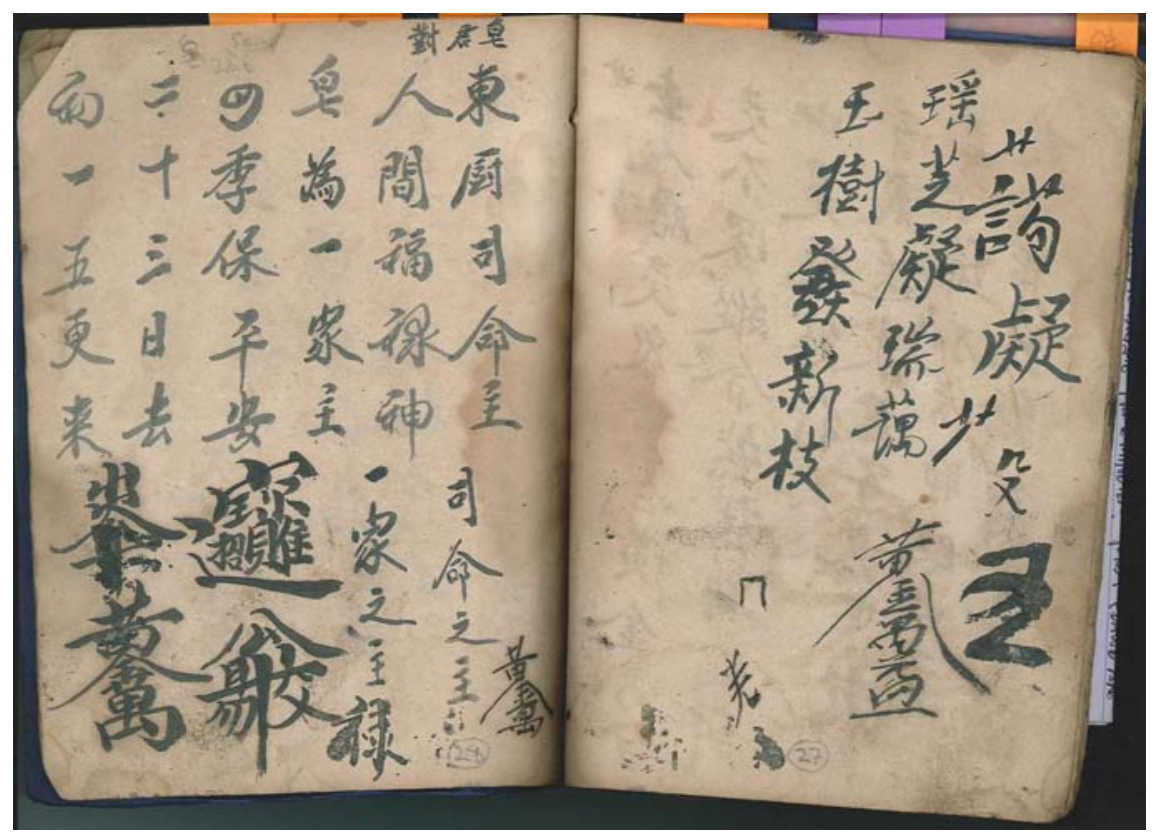

FIGURE 7.9

Mr. Bai's Notebook [Bai xiansheng zhi chaoben 白先生之抄本], Pages 27 and 28, Messy Pages. These show the messy format of the notebook that Mr. Bai prepared for his own use, with haphazard writing all over the page, such as some combined characters on the bottom half of both pages. The jumbled organization of some pages indicates that Mr. Bai worked quickly, jotting down ideas and information as they came to him.

Рното вY AUTHOR

Mr. Bai's village probably did not have too many homes with large courtyards or with more than one gate. He had the category of New Year duilian for the "main gate" [chongmen dui 重門對; pp. 17 and 18, six examples]. He also had a category of couplets for the "rear gate" [houmen 後門對, which Mr. Bai wrote in a simplified style as 后门對]; pp. 23 and 24, six examples]. This indicates that enough families had rear gates that Mr. Bai expected some requests for couplets for these gates as well. If he was living in a rural area with agriculture and animal husbandry, then the gate to the pen behind the main family home or courtyard where the animals were kept would be referred to as the rear gate of the family. Thus even a family of little or only moderate means might have both a front and a rear gate on their property. ${ }^{13}$

13 This pattern of a family compound with a front gate that also had a rear gate for the animal pen or threshing ground behind the compound in a village community in Shandong in the 


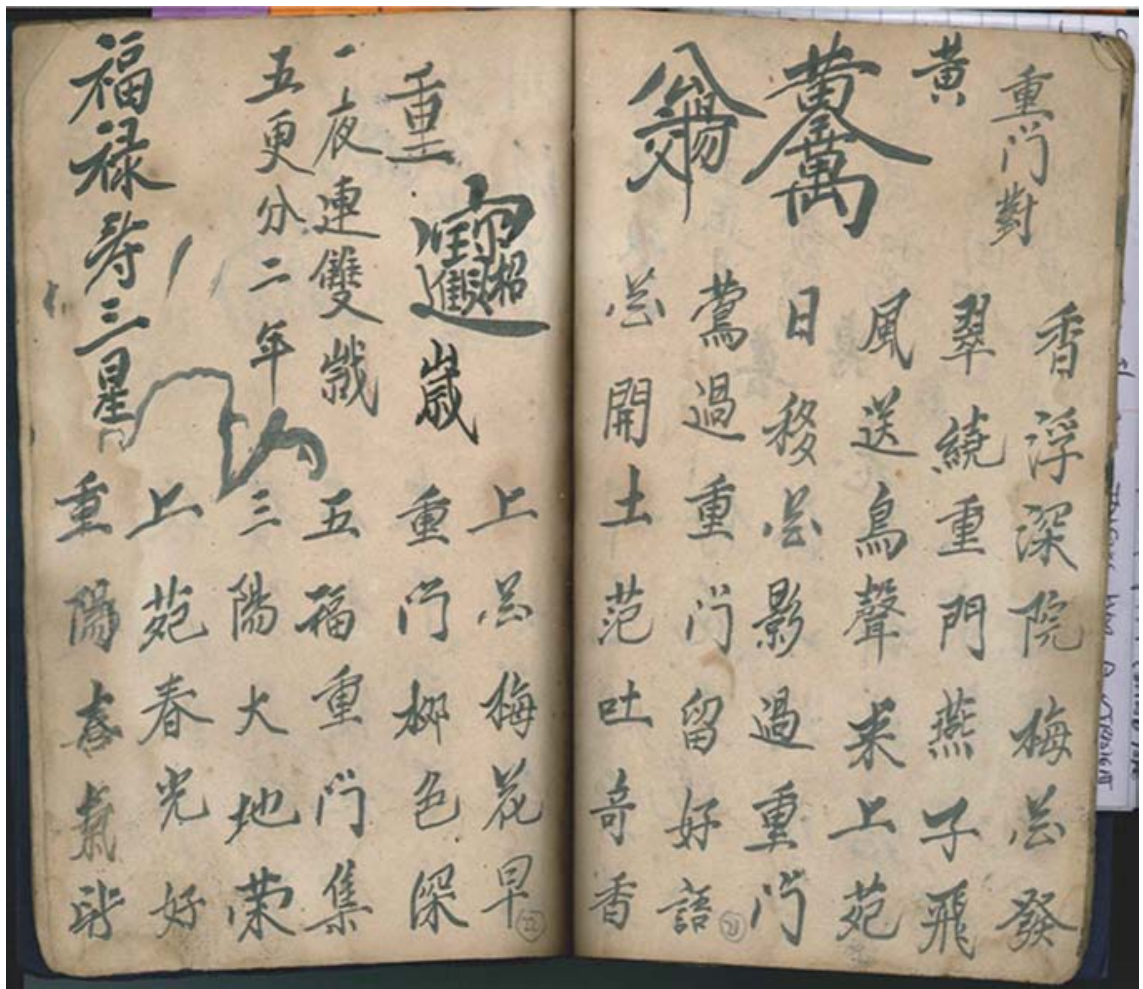

FIGURE 7.10

Mr. Bai's Notebook [Bai xiansheng zhi chaoben 白先生之抄本], Pages 21 and 22, Combined Characters. On the top half of these pages are examples of some combined characters [hetizi 合 體字] that were popular symbols for celebratory scrolls, especially for the New Year's holiday. Рното BY AUTHOR

On happy occasions, the Chinese also write celebratory characters that are not used in ordinary writing. The result, which combines several characters into one, looks complicated as well as picturesque. These usually celebratory characters have no pronunciation of their own. Mr. Bai wrote several of these characters in his notebook to help him remember how they should be written. This indicates that Mr. Bai's formal schooling was not extensive. A fully educated and literate member of society would not need that written clue, especially since these characters are referred to by the combination of each of the characters that goes to make them up. For example, the character for

late 1800 is mentioned in Ida Pruitt, A China Childhood (Beijing: Foreign Languages Press, 2003). 
"Bringing in wealth and treasures" is made up of the characters for those words [zhaocai jinbao 招財近寶]. In Mr. Bai's own handwriting, the combined character appears as 通 (on p. 22). This seems to be the most popular combined character in the present day, and an example online is 邀. Mr. Bai also wrote "ten thousand liang (a unit of weight equivalent to 1.76 ounces) of yellow gold" [wanjin wan liang 萬金萬兩], which appears in his handwriting as 蓄 (on p. 21). A standard representation of the character online is: 素. This phrase is sometimes modified to read "ten thousand ounces of yellow gold" [huang jin wan liang 黄金萬両], as in example above and in Mr. Bai's calligraphy (p. 27). He also wrote "easily acquire silver" [gong ping jiao yi 公平交易] 络-. (on p. 21). ${ }^{14}$

A death in the family was another event that called for a ceremonial banner. Unlike the typical celebratory banner written in black or gold ink on red paper, funeral banners were written in black ink on white paper. Red and gold are the colors of marriage and celebrations in China, but black and white are the colors of mourning. Mr. Bai may have hoped for commissions to write this type of banner, so he wrote a few sample phrases (on pp. 10 and 11, eight examples) for his own reference and to offer his customers. He wrote six examples of eulogistic funeral couplets, all in seven-word formats. An example: "At the end, we are only required to keep three years of mourning; Yet we always keep in our hearts a deeper emotion" [Zhenzhongshun, jinsannianxiao; Zhuiyuanchangcun, yipianxin 真終順, 盡三年孝; 追遠常存, 一片心, p. 10]. These are expressions of condolences still in use today. The three years of mourning referred to the Confucian exhortation to observe three years of mourning (actually twenty-seven months) after the death of one's parents. Common people did not have the means to withdraw from society or to curtail their daily activities in order to express mourning, and even busy officials who wanted to follow the custom in its strictest form were often asked by the government to return to normal duties after only a few months of active mourning.

Mr. Bai's village probably had a number of small temples or shrines to the deities whose powers would protect the local community. The deities he specifically listed in his notebook were largely folk gods, such as the kitchen god [zaojun 皇君, p. 28, four examples]. Year-end celebrations of the kitchen

14 Combined characters are explained and several examples given in Zhang Daoyi 張道 一, Meizai hanzi: chuantong minjian meishuzi 美哉漢字: 傳統民間美術字 [Beautiful Characters: Traditional Popular Artistic Characters] (Shanghai: Shanghai wenyi chubanshe, 2012), pt. 1, 14, 103-106; pt. 2, 82. These elaborate characters were originally used by merchants to decorate their shops. See Shiyong Zhongguo fengsu cidian 實用中國風俗 詞典 [Practical Dictionary of Chinese Folk Customs] (Shanghai: Shanghai cishu chubanshe, 2013), 405. 


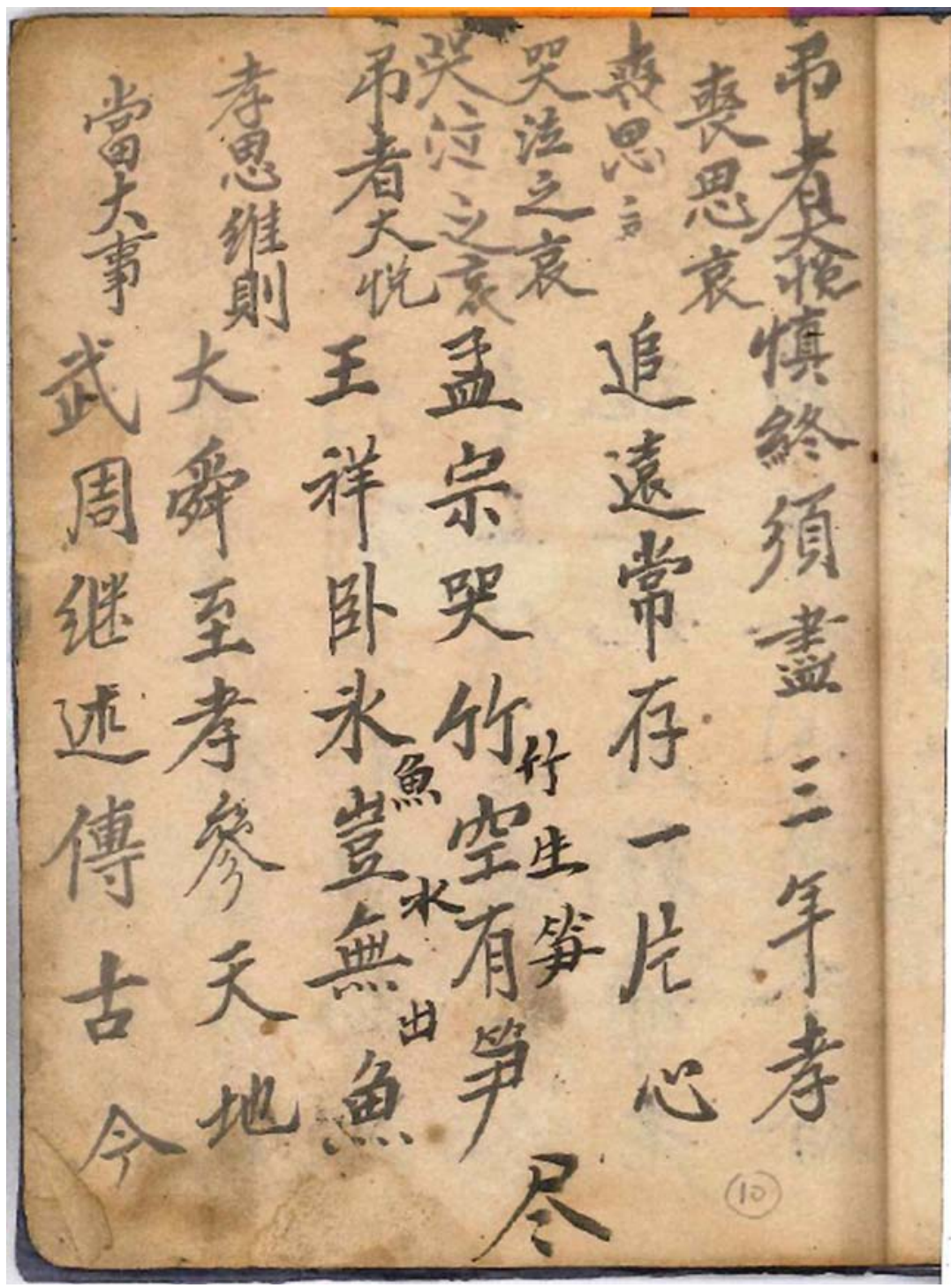

FIGURE 7.11

Mr. Bai's Notebook [Bai xiansheng zhi chaoben 白先生之抄本], Page 10, Funeral Inscriptions. Funerals were commemorative times when the couplets were written in black ink on white paper. On page 10 in the first and second long vertical lines, Mr. Bai wrote: "At the end, we are only required to keep three years of mourning; Yet we always keep in our hearts a deeper emotion" [Zhenzhongshun, jinsannianxiao; Zhuiyuanchangcun, yipianxin 真終順, 盡三年孝; 追遠常存, 一片心]. Accepted custom called for three years of mourning following the death of a parent, but the practice was not always followed, especially by the common people who did not have the luxury of retiring from work for a three-year period.

Рното BY AUTHOR 
god were popular in all parts of China. In late December, the kitchen god would leave his post near the household's stove and rise to the heavens to report to the Jade emperor [Yuhuang dadi 玉皇大帝] on family events. In hopes of securing a favorable report, the family would celebrate with sweetmeats and would perhaps rub sugar candy on the image of the kitchen god. ${ }^{15}$

Equally popular at the local level throughout China was worship of the Dragon King of the Well [Jinglongwang 井龍王, p. 32, four examples]. In a basically agricultural economy that had little rain, as in North China, water was vital. When water became scarce, local officials joined with village and city residents to propitiate the gods of water and beseech them to send rain. ${ }^{16}$ Another deity worshiped in the drier flat lands of North and Northeast China was the King of Horses [Mawang 馬王, pp. 38-39, three examples]. He was worshiped by the wagon drivers who transported goods and crops over long distances. If Mr. Bai's village was on a transportation route that utilized horses and mules, we might expect that the wagon drivers to frequent the King of Horses shrine before embarking on a long journey. The Manchus who lived in Northeast China and in North China especially honored the King of Horses. ${ }^{17}$

15 Many rural villages, such as the one I hypothesize where Mr. Bai lived, had no temples or very few temples in the Republican period. Comments on this situation are made by Thomas DuBois, "Village Community and the Reconstruction of Religious Life in Rural North China," in Religion and Chinese Society, vol. 2: Taoism and Local Religion in Modern China, ed. John Lagerwey (Hong Kong: Chinese University Press, 2004), 2: 847852. Popular worship of the kitchen god around the time both Mr. Bai and Mr. Qian (discussed below) were alive is in Tun, Annual Customs and Festivals in Peking, 98. Lowe, The Adventures of Wu, Annual Customs and Festivals in Peking, 98; see also 2: 22-23, 145146. A description of this deity is in Zhang, Daojiao shenxian xinyang, 508-510; Kubo, Dōkyō no kamizami, 271-273. For a text-based approach to this subject, see Robert L. Chard, "Rituals and Scriptures of the Stove Cult," in Ritual and Scripture in Chinese Popular Religion: Five Studies, ed. David Johnson (Berkeley: Chinese Popular Culture Project, 1995), 3-54.

16 Both Daoist and Buddhist temples might be dedicated to the dragon kings. On praying for rain, see Snyder-Reinke, Dry Spells. A hand-copied text in my collection titled Ceremonies for the Dragon Kings [Longwang fashi 龍王法事] addresses many Buddhist dragon kings. Dated 1902, renyin nian 王寅年, it is 9 in $(22.86 \mathrm{~cm}) \mathrm{h} \times 5^{1 / 4}$ in $(13.33 \mathrm{~cm}) \mathrm{w}$ and was purchased in Beijing in January 2010. This has thirty-four pages of handwritten text calling on many dragon kings for help. A concise overview of dragon king worship is Longwang 龍王 [Dragon King], https://baike.baidu.com/item/\%E9\%BE\%99\%E7\%8E $\% 8 \mathrm{~B} / 28349$, accessed in August 2012, August 2017. This work is also discussed in Chapter 8.

17 The King of Horses was also known as Chief of the Horses [Mayuanshuai 馬元帥] and Pasture and Water Brilliant King of Horses [Shuicao mamingwang 水草馬明王]. See Chen Bali 陳巴黎, Beijing dongyuemiao 北京東获廟 [Beijing's Temple of the Eastern 
Throughout the dry northern lands, fire was an ever-present danger. Thus Mr. Bai's community contained a temple to the fire god [huoshen 火神; p. 33, five examples]. In the populated capital city of Beijing in dry North China, even the imperial court sent officials to worship at the altar of the fire god on behalf of the entire community. The god's charge was to protect against fire. ${ }^{18}$

In premodern China, diseases resulting from a lack of basic sanitation and an unclear understanding of personal hygiene led to many afflictions that were brought under widespread control only in the twentieth century. Among such diseases was trachoma, a viral disease characterized by excessive inflammation and itching of the eye. Both adults and children easily contracted trachoma while Mr. Bai was alive, and many communities turned for help to the Buddhist Deity of Clear Sight [Yanguang 眼光]. Even several widely visited temples in present-day Shanghai contain altars dedicated to the Deity of Clear Sight because trachoma continued to be prevalent in China in the 1950s. Mr. Bai also wrote couplet to this deity (p. 39, one example). ${ }^{19}$

Peak] (Beijing: Zhongguo shudian, 2002), 75-76. Worship of the King of Horses is mentioned in Tun, Annual Customs and Festivals in Peking, 55; Lowe, The Adventures of Wu, 2: 209-210. See also “Xingyeshen xinyang; Maluolu yunshuye 行業神信仰; 馬騾䯓運輸 業 [Popular Beliefs in the Gods of Transport; Horses, Mules and Donkeys in the Transport Industry]," http://www.sanching.org.tw/joinus_3/eq_detail.php?idno=75/, accessed August 1, 2012. On the Manchus in Northeast and North China, especially honoring the King of Horses, see Guan Zhiwei 關志偉, ed., Jilin Manzu fengsu 吉林滿族風俗 [Customs of the Manchu in Jilin] (Changchun: Jilin renmin chubanshe, 2006), 310-311.

The fire god is titled Virtuous Perfected Ruler of Fire [Huode zhenjun 火徳真君]. On the imperial court dispatching officials to worship at the Fire God Temple in Beijing near the Houhai 後海, see the pamphlet Huoshenmiao 火神廟 [Fire God Temple] (Beijing: Beijing Huode zhenjunmiao, 2010). See also Lowe, The Adventures of Wu, 1: 210; Kubo, Dōkyō no kamigami, 268-270.

19 On writing scrolls to various deities and spirits, see Clifford H. Plopper, Chinese Religion Seen Through the Proverb (New York: Paragon Book Reprint, 1969). The book was originally published in Peking in 1924, reprinted in Shanghai in 1935. Other titles of the Deity of Clear Sight are: Holy Mother of Clear Sight [Yanguang shengmu 眼光聖母], Clear-Sighted Bodhisattva [Yanguang pusa 眼光菩薩], Buddhist Bodhisattva of Clear Sight [Foyan pusa 佛 眼菩薩], and Auntie Clear Sight [Yanguang niangniang 眼光娘娘]. In theological terms, this deity could also open one's eyes to the truth of Buddhist teachings. She is still worshiped in Shanghai, see Ding Changyun 丁常雲 et al., Yinciyangdian yu Dongyue xinyang 飲賜仰殿與東訔信仰 [The Yinci Hall and Belief in the Emperor of the Eastern Peak] (Shanghai: Shanghai zishu chubanshe, 2004), 16o. I saw her altar in the Shanghai City God Temple in January 2013, where she resides in the Cihang dian 慈航殿 [Hall of the Vehicle of Compassion]. See the pamphlet Shanghai chenghuang miao 上海城隍廟 [Shanghai City God Temple] (Shanghai: Shanghai chenghuang miao daoguan, n.d.). She has her own 
Mr. Bai's community also worshiped the Grandfather of Heaven [Laotianye 老天爺, p. 30, three examples]. ${ }^{20}$ Mr. Bai suggested worshiping the Grandfather of Heaven with the couplet "He institutes the wind, clouds, thunder, and rain; He ties together the sun, moon, stars and daybreak" [shifeng, yun, lie, yu; xiri, yue, xing, chen 施風, 雲, 雷, 雨; 繫日, 月, 星, 晨; p. 30]. Yet another deity popular among the people was the deity who could quell troublesome ghosts and so keep misfortune away. He was called the Middle Chief [Zhongkuiye 中魁爺; p. 31, two examples] whose image was often pasted on one of the front gates, along with that of a god of wealth [caishen 財神]. ${ }^{21}$

These deities whose altars were part of Mr. Bai's community were not (except for Laotianye) the highest deities in the Daoist or Buddhist pantheon but, rather, were popular religious figures who were close to the laboring populations of rural villages. They had a direct relevance to the occupations and efforts of the village people to feed themselves, earn a livelihood, and protect their families. Minor god's temples and shrines could be ornate but were usually not grand or impressive and rarely consisted of multiple buildings or large courtyards. But they probably saw a steady stream of individuals on most days who

hall within the Yunfeng Temple [Yunfengsi 警埄寺]. See "Yunfengsi jingchu jieshao 藝 埄寺景初介紹 [Introducing the Yunfeng Temple Area]," at http://www.chinanews.com .gj/kong/news/2007/12-23/111235o.shtml, accessed on August 1, 2012. See also Nara Yukihiko 奈良行博, Chūgoku no kichijō bunka to dōgyō: Shukusai kara shiru Chūgoku minshū no kokoro 中国の吉祥文化と道教; 祝祭から知中国民眾の心 [Chinese Festival Culture and Daoism: Understanding the Heart of the Chinese People through Their Celebrations] (Tokyo: Myōseki shoten, 2011), 139. See also Kubo, Dōkyō no kamigami, 216.

20 Laotianye is the popular name for the Jade emperor. In Mr. Bai's community this must have been the way most people referred to the Jade emperor. Connection between the two titles is in Anne S. Goodrich, Peking Paper Gods: A Look at Home Worship (Nettetal: Steyler, 1991), 18. This deity is associated with the term God on High [shangdi 上帝]. See http://baike .baidu.com/view/668871.html, accessed August 1, 2012. See also Zhang, Daojiao shenxian xinyang, 223-226; Kubo, Dōkyō no kamizami, 129-131.

21 Zhongkuiye is said to be fierce and active, able to subdue and drive away evil spirits and ghosts. When given the name Zhongkui, he acts as a door guard, and his image will be pasted on the left side of the gate (as seen when approaching the home). A book of his adventures is Chan Kok Sing (illus.) and Geraldine Goh (trans.), Adventures of the Chinese Ghostbuster (Singapore: Asiapal Books, 2008). See also "Zhong Kui Hometown," at http:// en.comelv.com/comcontent_detailıo/\&FrontComContent_list.html, accessed August 1, 2012. Many illustrations of this are in Shen Hong 沈泓, Zhongguo jingshen: minjian tuxiangzhong de xinyang huanying 中國精神: 民間圖像中的信仰幻影 [The Chinese Spirit: Popular Imagination as Reflected in Folk Images] (Beijing: Zhongguo caifu chubanshe, 2013), 79-94. A full-length study of this deity is idem, Zhong Kui wenhua 鐘馗文化 [The Culture of Zhong Kui] (Beijing: Zhongguo wuzi chubanshe, 2011). 


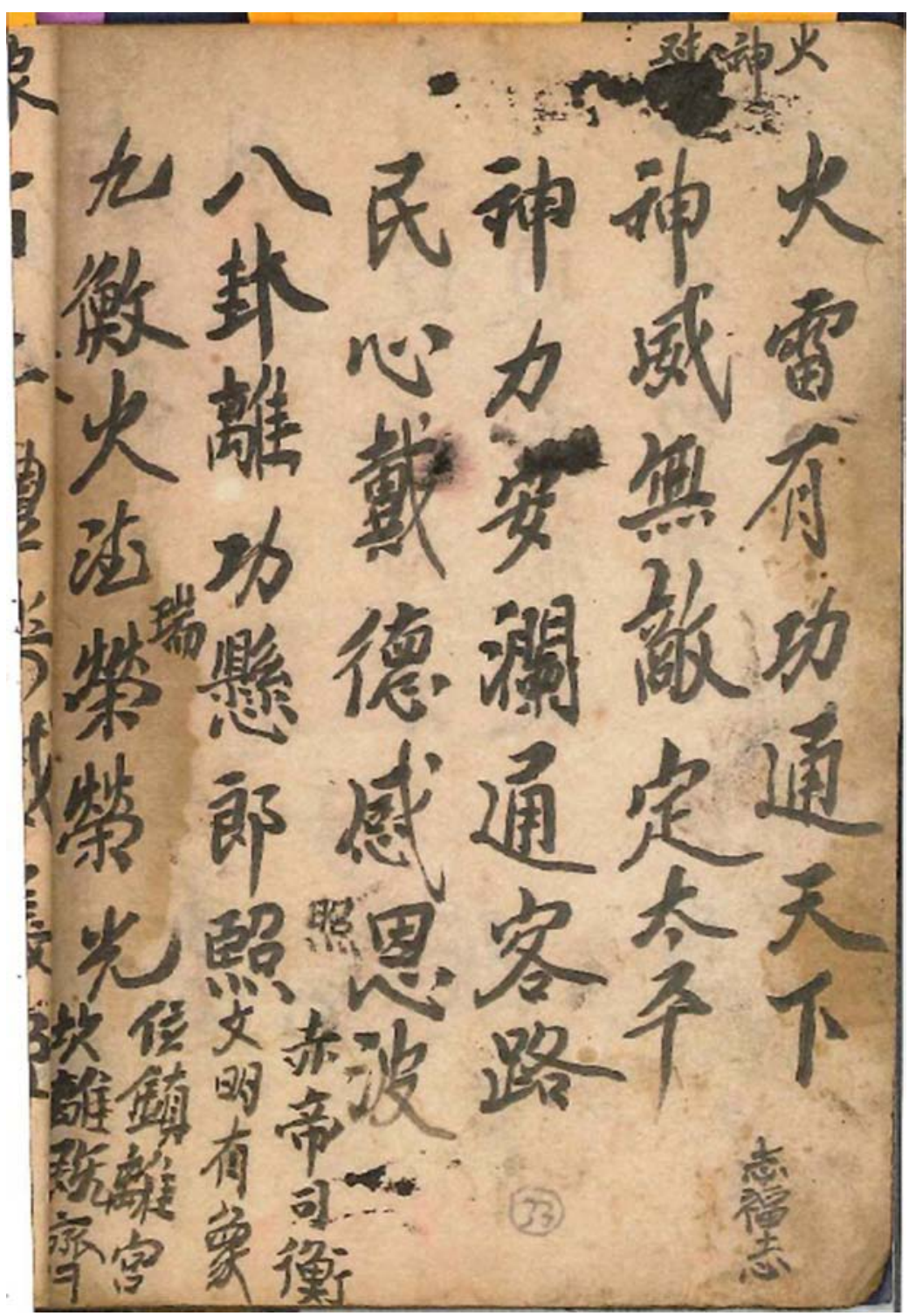

FIGURE 7.12

Mr. Bai's Notebook [Bai xiansheng zhi chaoben 白先生之抄本], Page 33, Honoring the Fire God. Mr. Bai prepared sample honorific phrases that might be purchased by the religious temples in his vicinity. These extolled the deities of popular religion, often claimed by both Buddhists and Daoists. Among them was the fire god [huoshen 火神], whose role was to protect against fire. In Buddhist thinking, fire was a cleansing element that could burn away ignorance and cravings. This was one of the virtues of the fire god, who was officially called the Virtuous Perfected Ruler of Fire [Huode zhenjun 火徳真君].

Pното BY AUTHOR 
would stop by to burn incense and ask for protection. Mr. Bai had couplets for each of the deities in his community.

Around the time Mr. Bai was writing his notebook, printed versions of couplets, including couplets that could be used at temples for various deities were available. The virtue of Mr. Bai's notebook for this study is that, in his book, he selected couplets only for the deities that were in his community because they were the only temples that might pay him to write a couplet. Thus we have an idea of the specific deities that were honored in Mr. Bai's community. ${ }^{22}$

On page 39 of his handwritten notebook, Mr. Bai gave future readers a great gift. He wrote what he must have thought was a clever couplet: "China's president is Yuan Shikai; The Republic's general is Li Yuanhong” [Zhonghua zongtong Yuan Shikai; Minguo dudu Li Yuanhong 中華總統袁世凱; 民國都督 黎元洪]. If he lived in a rural village, Mr. Bai was showing off his knowledge of faraway national events by preparing this couplet. It is not likely anyone in the village would order such a couplet for their gateposts, but it helps to date this text fairly precisely.

The revolution that toppled the Qing dynasty unfolded in the final months of 1911. In those months, Li Yuanhong was appointed Commander of the Military Government of Hubei Province. ${ }^{23}$ In the popular mind, he continued to carry this heroic title with him into the events of the following two years. The Hubei regional government was important because the first capitulation of Qing troops took place in Hubei province, and the new "government" that quickly formed to fill the power vacuum that suddenly emerged was considered an especially heroic and nationalistic (pro-Chinese, anti-Manchu) body. Yuan

22 An example of New Year and religious couplets that were likely available to Mr. Bai is the book titled A New Collection of Regular and Commercial Couplets 共和普通商用對 聯新編 [Gonghe putong shangyong duilian xinbian], ed. Master of the Qingyunxuan (n.p., 1915). I bought it in Changchun, Jilin Province, in December 2012. It is two volumes bound together, vol. 1 of nineteen folio pages, vol. 2 of twenty-three folio pages.

23 Li Yuanhong received his appointment as Commander of the Military Government of Hubei on October 17, 1911. See Zhu Ping 朱平, Minguo fan'er 民國范兒 [The Pattern of the Republic] (Haikou: Nanfang chubanshe, 2012), 154. See also Lan Xiaoli 蘭曉麗 et al., ed., Li Yuanhong dazhuan:Cong pinhanshusheng dao shouyidudu 黎元洪大傳; 從貧寒書 生到首義都督 [Li Yuanhong: From Poor Student to Leading Military Governor] (Wuhan: Huazhong kejidaxue chubanshe, 2011), see the chronology on p. 308. See also Edward J.M. Rhoads, Manchus and Han: Ethnic Relations and Political Power in Late Qing and Early Republican China, 1861-1928 (Seattle: University of Washington Press, 2000). Li Yuanhong became interim vice-president on February 20, 1912, and vice-president of the Republic on October 7 , 1913. I believe Li Yuanhong's title as military commander was popularly ascribed to him even after 1912. 


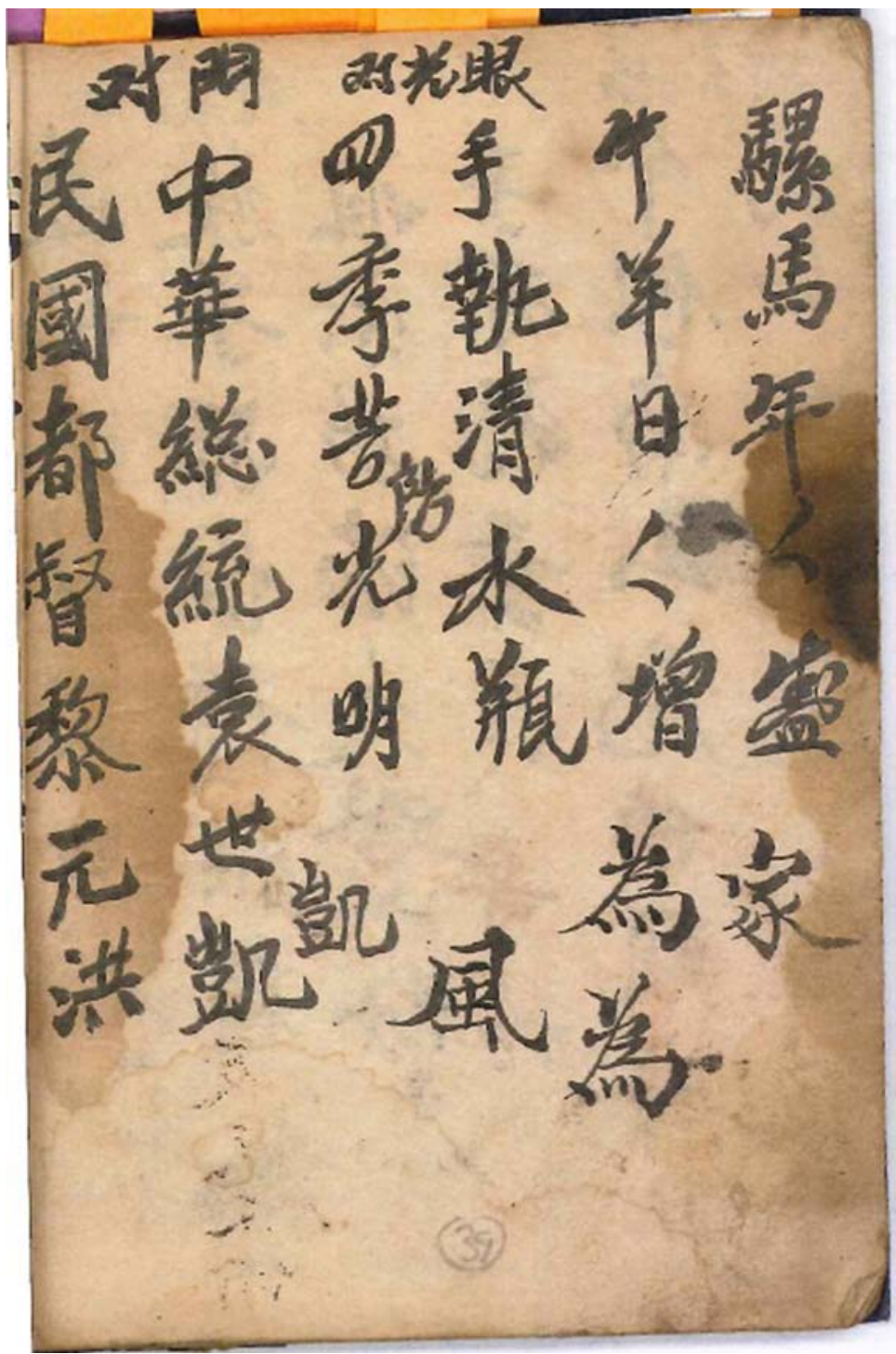

FIGURE 7.13

Mr. Bai's Notebook [Bai xiansheng zhi chaoben 白先生之抄本], Page 39, Phrase Written in 1913. Mr. Bai prepared a phrase that no one was likely to order for a scroll because it fell outside the accepted phraseology. But it allowed Mr. Bai to show that, as a person with some formal education, he was better informed about world events than most people in his community. He wrote: "China's president is Yuan Shikai. The republic's general is Li Yuanhong" [Zhonghua zongtong Yuan Shikai. Minguo dudu Li Yuanhong 中華總統袁世凱；民國都督黎元洪]. This phrase indicates that this booklet was probably written early in 1913, about a year after the birth of the Republic of China [Zhonghua minguo 中華民國].

PнОTO BY AUTHOR 
Shikai had been a Qing general in North China, but by the end of 1911 he had switched sides and joined the cause of the Revolution. He was named president of the new Republic of China in March 1912. He kept that title until December $1915 \cdot{ }^{24}$

Based on these historical events, it seems most likely that Mr. Bai wrote his couplet in 1912 or the early months of 1913, when many ordinary Chinese who heard of these events still felt the thrill of having brought down the Qing dynasty, and so they liked to refer to their hero Li Yuanhong by his military title. With this notebook, Mr. Bai has given us a view of his attempts to earn a living by tutoring students and selling celebratory matched couplets in his small rural village in North China in literally the first years of the Republic of China.

\section{Mr. Qian}

One way to better understand Mr. Bai and the context of his life is by comparing and contrasting his work with that of another man doing similar work at roughly the same time. A month after I bought Mr. Bai's notebook in Beijing, during my trip to China in the spring of 2012, I bought a similar handwritten book of couplets at a shop in Hangzhou, and the owner told me he had brought the book from his hometown of Kaiping 開平 in Guangdong Province. The second book was written by another man, whom I named Mr. Qian 錢. This character means "money" or "cash," and I use it for him because he was a successful writer of duilian. ${ }^{25}$

Mr. Qian used a better quality of handmade paper for his book than Mr. Bai. Though still not of the highest quality of paper available, his paper had been bleached and so was whiter, though just as pliable as the inexpensive paper used by Mr. Bai. Mr. Qian had acceptable calligraphy, indicating that

24 Yuan Shikai was appointed interim president of the Republic [Linshi dazongtong 臨時大 總統] on February 15, 1912. Most likely, Mr. Bai did not have access to the latest national news. Indeed, few people at the time in China had regular access to the latest news. Many examples are given in Jane E. Elliott, Some Did It for Civilization, Some Did It for Their Country: A Revised View of the Boxer War (Hong Kong: Chinese University Press, 2002).

Kaiping, which I believe was the hometown of Mr. Qian, is located southwest of Guangzhou (Canton). From the 18 oos on, many Kaiping residents went abroad, and most of them sent money back home, which boosted the local economy. Some gazetteers for Kaiping County are in Ming-Qing shike wenxian quanbian 明清石刻文獻全編 [Complete Texts of Stone Inscriptions and Documents from the Ming and Qing] (Beijing: Beijing tushuguan chubanshe, 2003). On Kaiping, see series 5, 2: 673-693. 
most likely he had more formal schooling than Mr. Bai and perhaps was even a xiucai. His calligraphy was good enough that he was likely to receive requests from educated or socially well-positioned people. Unlike poor Mr. Bai in North China, Mr. Qian in South China appeared to live in a larger and economically and culturally more vibrant community, where he had numerous potential customers for his couplets. He seems to have been familiar with the protocols of the educated and moneyed social elite. ${ }^{26}$

Mr. Qian's manuscript was neatly written out, with no mistakes and no corrected characters. The pages are not smudged and do not appear to have been roughly handled, as if Mr. Qian could quickly refer to the text he wished to copy and then proceed in an orderly manner to write the characters. The sixtytwo pages in his book, measuring $63 / 4$ inches $(17.1 \mathrm{~cm}) \times 4-7 / 8$ inches $(12.4 \mathrm{~cm})$, are not complete-the cover and earliest pages are missing, but the intact pages are well prepared and the only calligraphy is that of Mr. Qian; unlike Mr. Bai, he did not have friends or students writing in his book. One could surmise that he was an orderly and organized person.

In Mr. Qian's notebook, the first category is devoted to New Year couplets. On pages 1-7, Mr. Qian prepared seventy-six examples of New Year couplets, in four-, five-, and seven-words-per-line versions. (Mr. Bai did not always label his couplets in neat categories, so I am unable to definitively compare the numbers of samples in each category with those written by Mr. Qian; in general Mr. Bai prepared a smaller number of duilian in each category.)

An equally good source of income for Mr. Qian must have been the couplets he prepared for weddings. He prepared twenty-five sample couplets for weddings, divided into six different categories, such as "Couplets for weddings and new households" [xinhun jian xinju 新婚兼新居; pp. 48 and 49, ten examples], "Elder brother officiates at wedding" [xiong zhu hun 兄主婚; p. 54, five examples], and "Father deceased, mother alive, grandfather officiates at wedding” [wufu youmu er zuzhuhun 無父有母而祖主婚; p. 55, two examples]. Mr. Qian's selection of sample couplets show that his clients were punctilious about family relationships and asked for couplets appropriate to their specific circumstances. In general, we can guess that those with a higher social standing and more wealth, Mr. Qian's assumed customers, were more specific in

26 North China is considered a poorer part of the country, where rainfall is low and agriculture is difficult. In contrast, because of its abundant rainfall and mild temperatures, South China has long been a wealthier area of the country where food was more abundant for everyone. Many wealthy merchant families lived in the south. Contrasts between these two regions of China are in Elman, Civil Examinations and Meritocracy in Late Imperial China. 


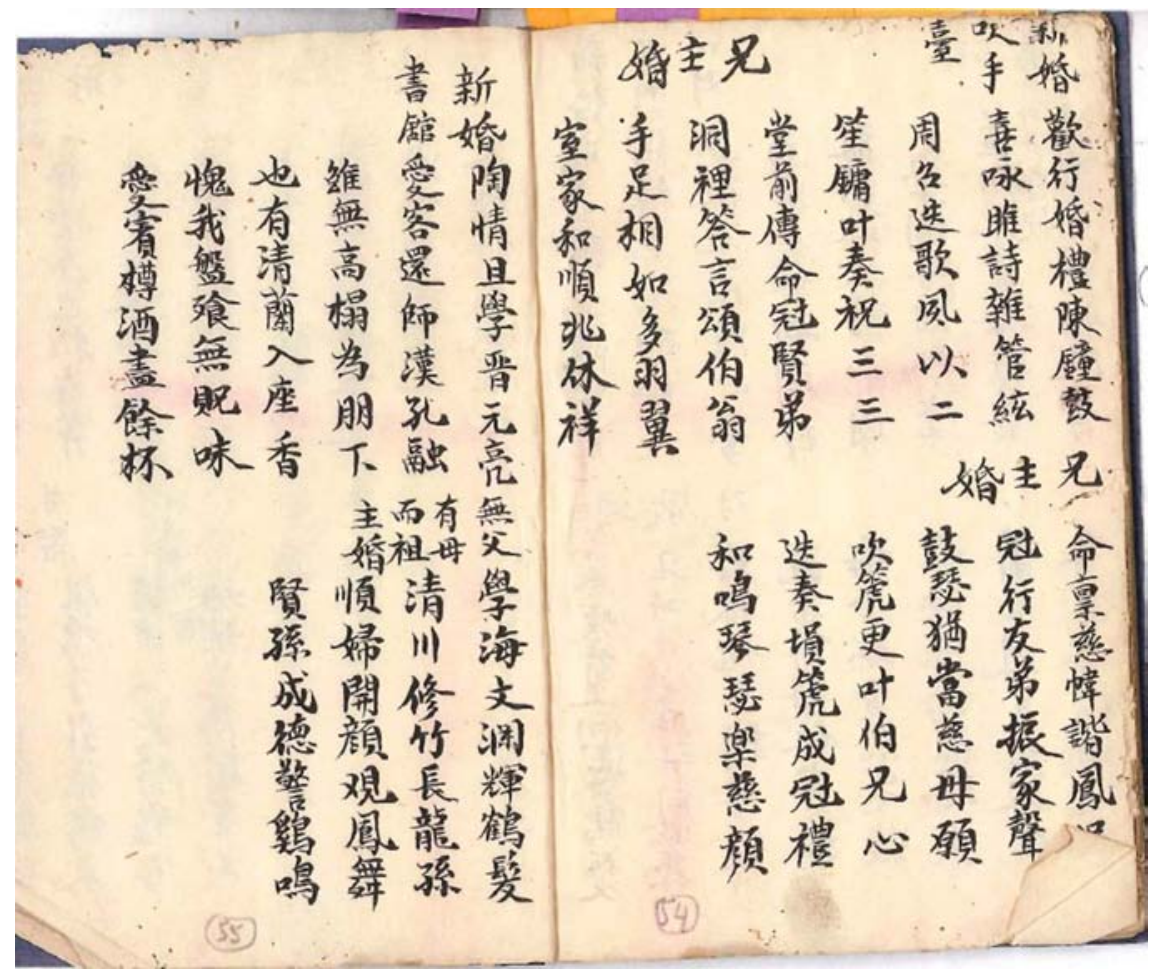

FIGURE 7.14

Mr. Qian's Notebook [Qian xiansheng zhi chaoben 錢先生之抄本], Page 54, A Wedding Couplet. The first two vertical line on the top half of the page read: "Carry out the wedding ceremony, sound the bell and drum; Happily sing out the poems, with flutes and strings" [Huanxing hunli, chen zhonggu; Xiyongju shi, zaguanxian 歡行婚禮, 陳鍾鼓; 喜咏睢詩, 雜管絃]. Mr. Qian expected to regularly receive orders for celebratory scrolls to be hung at weddings. He also expected that many of his clients would be spending lavishly to make the wedding a festive occasion.

Рното BY AUTHOR

acknowledging and honoring the complicated set of familial relationships within their kinship network than were the pingmin, who had lower income and social status. The relatively well-off wanted to use important family occasions to enhance or reinforce their social position. The wedding proceedings in these more affluent households might include musicians, for whom Mr. Qian could offer sample texts for couplets celebrating the musicians, under the category of “musicians at the wedding” [xinhun chuishoutai 新婚吹手臺; p. 54, two examples]. One of these couplets reads, "Carry out the wedding ceremony, sound the bell and drum; Happily sing out the poems, with flutes and strings" [huanxing hunli, chen zhonggu; Xiyongju shi, zaguanxian 歡行婚禮, 陳鍾鼓; 喜 咏睢詩, 雜管絃; p. 54]. 
In addition to these standard categories of social events that most likely guaranteed orders for couplets, three other categories of couplets given prominence in Mr. Qian's book show that he lived in a community with a number of large and financially comfortable families. The first category that indicates large and wealthy families consists of a large number of samples Mr. Qian prepared for people wishing to decorate their homes with couplets. On thirteen different pages, Mr. Qian was prepared to offer seventy samples of texts, divided into twelve categories. The large number of sample texts and the multitude of categories indicate that the people he catered to resided in large homes, with several gates and courtyards within their walls, many of whom owned farm land and animals, who would pay to have couplets put up throughout their compound. These houses not only had a main gate and a back gate but sometimes also had inner gates they wanted decorated, so Mr. Qian prepared sample texts for the category of “New Year, Inner Gates" [xinchun langmenkou 新春廊 門 $\square$, p. 8; eight examples]. Parents who lived with their children could be given a separate courtyard with its own gate, which could be decorated with couplets in the category of "parents' gate" [ fumu menkou 父母門 $\square$; p. 13, seven examples]. ${ }^{27}$

Among established gentry families in South China, several males in each family were likely to be well educated, and some of these families established private libraries within their compounds with collections of woodblock printed books, paintings, and calligraphy. They might want a couplet for their personal collection of treasures from the category "couplets for the library" [shuguan$d u i$ 書館對; pp. 31-33, twenty-four examples]. (These sample texts were not intended for commercial book sellers, a separate category mentioned below.) If a new library within the family compound was organized at the time of the wedding for one of the sons, a couplet could be prepared from the category “new marriage, library" [xinhun shuguan 新婚書館; p. 55, three examples]. Wealthy families likewise were known to maintain a clan hall in honor of their ancestors, in the category of "couplets to worship the ancestors" [zucidui 祖祠 對; pp. 43-45, sixteen examples]. Four of the examples (pp. 43 and 44) contain texts that are fifteen, sixteen, or seventeen characters long in each line. Examples of that length could be written out on two scrolls, or they could be carved into the wooden pillars supporting the roof, thus becoming permanent celebratory texts, rather than the texts written on paper, which might be changed

27 For examples of the wealth of southern merchants, see Yi Wen, Shang zhi Jiangnan 商之 江南 [The Commerce of Jiangnan] (Shanghai: Shanghai yuandong chubanshe, 20o9). This is a bilingual edition that includes photos of the homes of well-to-do merchants and the connected courtyards of that architectural style. 


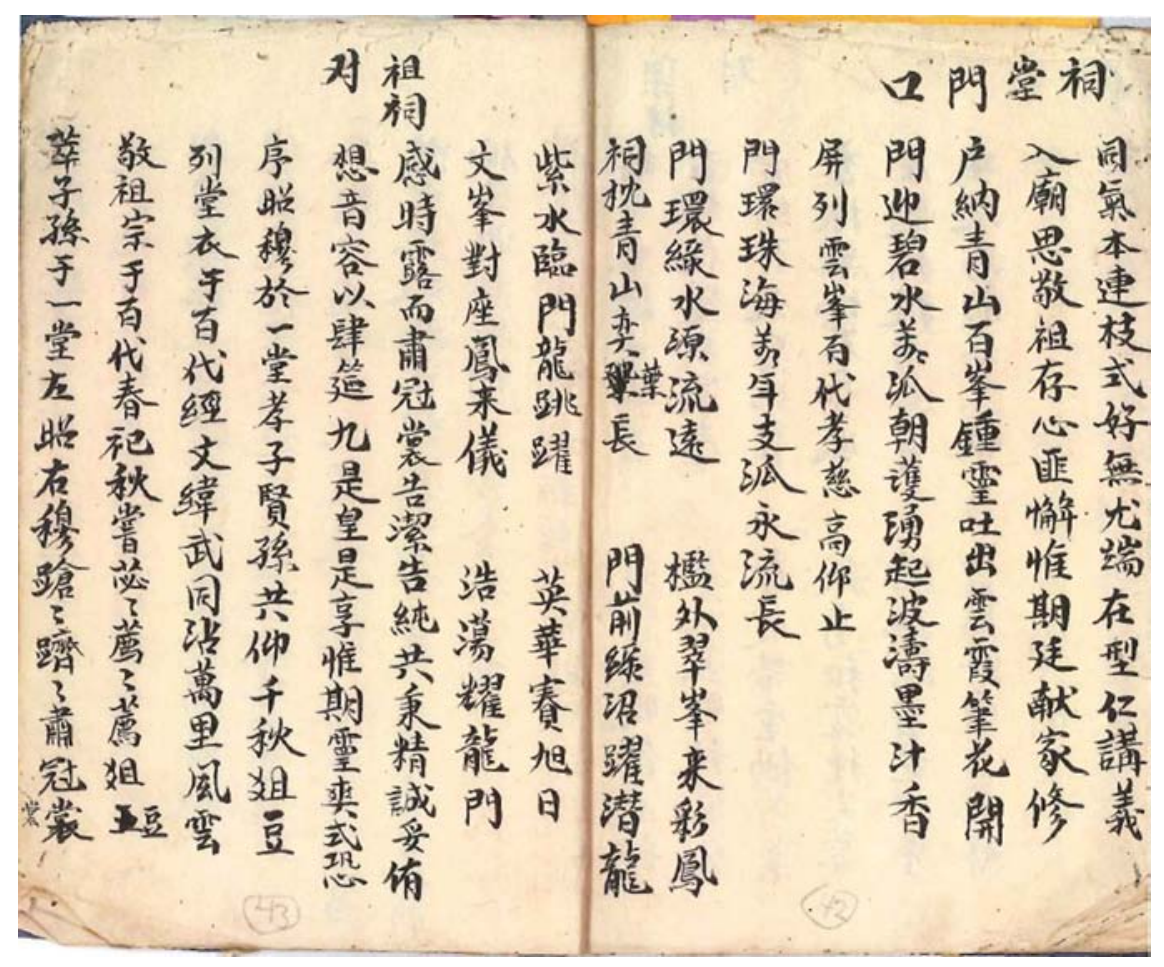

FIGURE 7.15

Mr. Qian's Notebook [Qian xiansheng zhi chaoben 錢先生之抄本]. Pages 42 and 43, Clan Temple Scrolls. Clan temples are especially prominent and have been well-maintained in South China, where I think Mr. Qian was working, so he prepared sample rhyming couplets to be hung in a family-run clan temple. At the top of page 42, he wrote "For Family Halls" [Citang menkou 祠 堂門口], and at the top of page 43, he wrote, “Scrolls for Ancestor Temples” [Zuci dui 祖祠對].

Рното вY AUTHOR

from time to time. The main entrance to the ancestral hall might receive a couplet in the category "worship hall entrance" [citang menkou 祠堂門 $\square ;$ p. 42, five examples].

Because such families lived in rich agricultural country with abundant rainfall and wet-rice agriculture, they needed sluice gates for regulating water flow to the fields, and this formed its own category of celebratory couplets (couplets for sluice gates [zhamendui 閘門對]; p. 23, four examples). Categories for other important buildings associated with rich family compounds were the shed where firewood was kept, "couplet for firewood room" [chaifangdui 柴房 對; p. 22, two examples], the chicken coop [ jilan 雞欄; p. 22, one example], and the cowshed, "couplet for the cowshed" [niulandui 牛欄對; p. 18, eight examples]. 


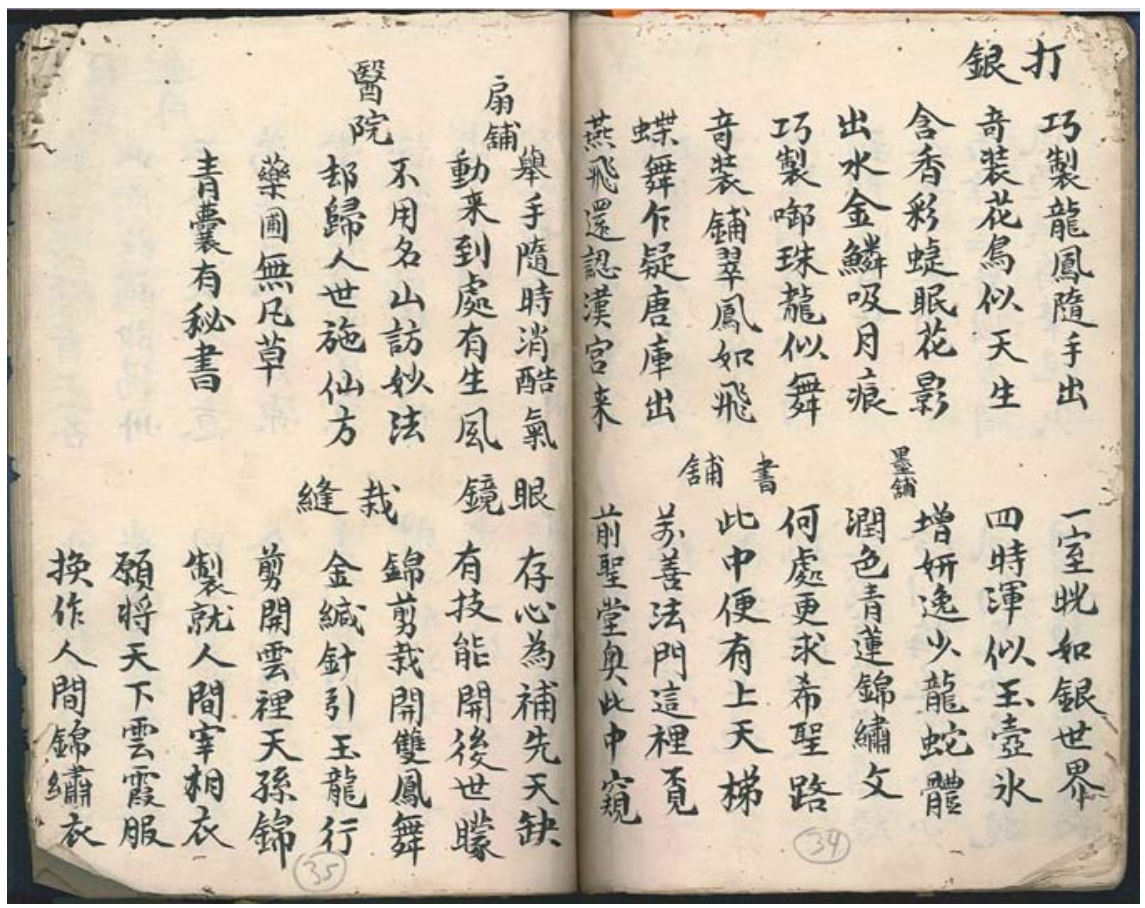

FIGURE 7.16

Mr. Qian's Notebook [Qian xiansheng zhi chaoben 錢先生之抄本], Pages 34 and 35, Scrolls for Shops. Mr. Qian prepared sample phrases for a variety of businesses. On page 34, he listed a few for silver ingot-casting shops [dayin 大銀], ink shops [mopu 墨舖], and bookstores [shupu 書舖]. His samples on page 35 were meant to appeal to owners of fan shops [shanpu 扇舖], medical clinics [yiyuan 醫院], eyeglass shops [yanjing 眼鏡] and tailors [caifeng 栽縫].

PHOTO BY AUTHOR

What poetic language might one use to celebrate the animals? An example suggested by Mr. Qian's was: "Cows and pigs all cry out abundance; chickens and dogs bring prosperity” [niuzhu jiechangsheng; Jiquan jinxinglong 牛猪皆昌盛; 雞犬尽興隆; p. 18]. Other couplets honor the kitchen god, under the category "couplets for the kitchen" [chufangdui 廚房對; p. 22, three examples].

Mr. Qian's community was economically vibrant. It supported a number of businesses, each of which was a potential customer for a celebratory couplet. Mr. Qian dutifully prepared sample couplet texts for each type of important business so that he would be prepared when requests for couplets were received. A general category was first prepared for those "used by all businesses" [shengyitongyong 生意通用; pp. 36 and 37, sixteen examples], much as Mr. Bai had done. But because Mr. Qian was more specific in the sample texts he prepared, by examining the texts he prepared and the business categories he listed, 
we can get an accurate picture of the economic activity surrounding Mr. Qian in Kaiping County.

Among the thriving businesses were silver casting shops [dayin 打銀; p. 34, five examples]. People brought in silver or other precious metals, which were melted into ingots in the shape of small bars or a boatlike shape called yuanbao 元寶, used as money or kept safely hidden away. ${ }^{28}$ Silver casting shops, along with the local pharmacies [yaocai 藥材; p. 41, six examples] were among the most likely to request congratulatory New Year couplets. A pharmacy might order a New Year couplet saying: "Within the jar is heaven, to cure everyone; Within the almond grove, there is nowhere without the spring winds" [huliyoutian jiehuayu; Xinglinwudi buchunfeng 菛裡有天皆化育; 杏林無地不春風; p. 41]. The jar [ $h u$ 盇] refers to the pharmacist's pottery jars in which herbs were kept. The almond grove [xinglin 杏林] refers to a place that supplies many of the herbs used in traditional Chinese medicine.

The other businesses in the community, for each of which Mr. Qian had several examples ready, were the Chinese ink shops [mopu 墨舖; p. 34, one example] selling the ink sticks and paraphernalia used for writing and painting, bookshops [shupu 書舖; p. 34, two examples], fan shops [which were important in the hot climate of South China; shanpu 扇舖; p. 35, one example], medical clinics [yiyuan 醫院; p. 35, two examples], shops selling eyeglasses [yanjing 眼 鏡; p. 35, one example], tailors [caifeng 栽缝; p. 35, three examples], pawnshops [dangpu 當舖; p. 38, three examples], florists [huazuo 花座; pp. 38 and 39, four examples], rice shops [mipu 米舖; p. 39, four examples], oil shops [youpu 油舖; p. 40, two examples], cloth-dyeing shops [ranfang 染房; p. 40, two examples], and metalworking shops [datie 打鐵; p. 40, two examples], some of which probably made cookware [guo 锅] and farm tools. Other shops produced and sold wine and spirits [jiuchang 酒廠; p. 53, four examples]. In anticipation of requests from merchants, Mr. Qian prepared sample couplets for the fishermen and the boat people who regularly transported goods by waterway [chuanjia yong 船家用; pp. 38 and 39, four examples]. Unlike Mr. Bai, who lived in a small community, Mr. Qian is most likely to have lived in a city or market center with many businesses.

28 After the silver had been cast into such ingots, they could be kept in the silver shop's storehouse under lock and key, as explained by Richard Yan-ki Ho in "Chinese Banking in the Nineteenth Century: The Case of Piaohao (票號)” (lecture delivered at the Fairbank Center for Chinese Studies, Harvard University, October 17, 2012). On money shops holding cash deposits, see Huang Jianhui 黃鍳暉, Shanxi piaohao shi 山西票號史 [A History of Shanxi Banks] (Taiyuan: Shanxi jingji chubanshe, 2008), 216-217. 
However, he did not include any listings for fortunetellers, ritual specialists, scribes, legal advisors, or the local schools. These exceptions indicate that the services offered by many licentiates were not recognized as small businesses with a storefront operation. The people in these categories could just easily set up a booth at a local temple fair, including local school teachers, who could offer these services as a sideline occupation, or those who were otherwise literate and offered a variety of these services as needed by the local pingmin.

Mr. Qian's community also hosted a larger number of temples or religious altars than did Mr. Bai's. Mr. Qian believed that these altars were a good potential source of income because couplets for them were likely to be requested, so he prepared eighty-five sample couplet texts for religious sites. Temples representing the most popular deities seemed likely to generate the most requests: for example, the Goddess of Mercy [Guanyin 觀音; p. 24, seven examples] and the Empress of Heaven [Tianhou 天后; p. 29, four examples], which referred to Mazu 媽祖 who is widely worshiped by communities in South China, especially those with ties to fishing and the sea. ${ }^{29}$ Temples dedicated to these deities were often fairly large so as to accommodate the large number of worshipers who came to pay their respects. Sample texts were also prepared for the kitchen god (p. 14, eight examples) and the earth gods [tushen 土神; p. 15, eight examples]. Equally common were the Heavenly Officials who confer blessings [Tianguancifu 天官賜福; p. 16, seven examples]. This category of deities often refers to the Three Officials, who are in charge of heaven, the earth, and water. ${ }^{30}$ Sample texts were prepared to honor gate gods [menguan 門官], well gods [ jingshen 井神; p. 22, four examples], and gods of the community altars [shetan 社 壇; p. 30, seven examples]. Gods of the community altars seem to have been more widely worshiped in South China than in the north. ${ }^{31}$ The Gods of the

29 On the importance of Mazu in Hong Kong, where she is referred to in Cantonese as Tinhau, see P.H. Hase, ed., In the Hearth of the Metropolis: Yaumatei and Its People (Hong Kong: Joint, 1997), 111-119.

30 On the Three Officials, see Chapter 1; their ranking is discussed in Chapter 8. Also see Beijing Baiyunguan: Tianxia daojiao diyi conglin 北京白雲觀：天下道教第一叢林 [Beijing Baiyunguan; The Most Important Daoist Monastery] (Beijing: Baiyunguan, ca. 2010), a bilingual edition with photos. See also Zhang, Daojiao shenxian, 240-244; for individual titles of the Three Officials, see Kubo, Dōkyō no kamizami, 156-158; Goodrich, Peking Paper Gods, 305-308.

31 On the importance of local altars and their greater presence in South China, see David Johnson, Spectacle and Sacrifice: The Ritual Foundations of Village Life in North China (Cambridge: Harvard University Asia Center, 2009), 325; David Faure, Lineage and Village in the Eastern New Territories, Hong Kong (Hong Kong: Oxford University Press, 1986), 74- 


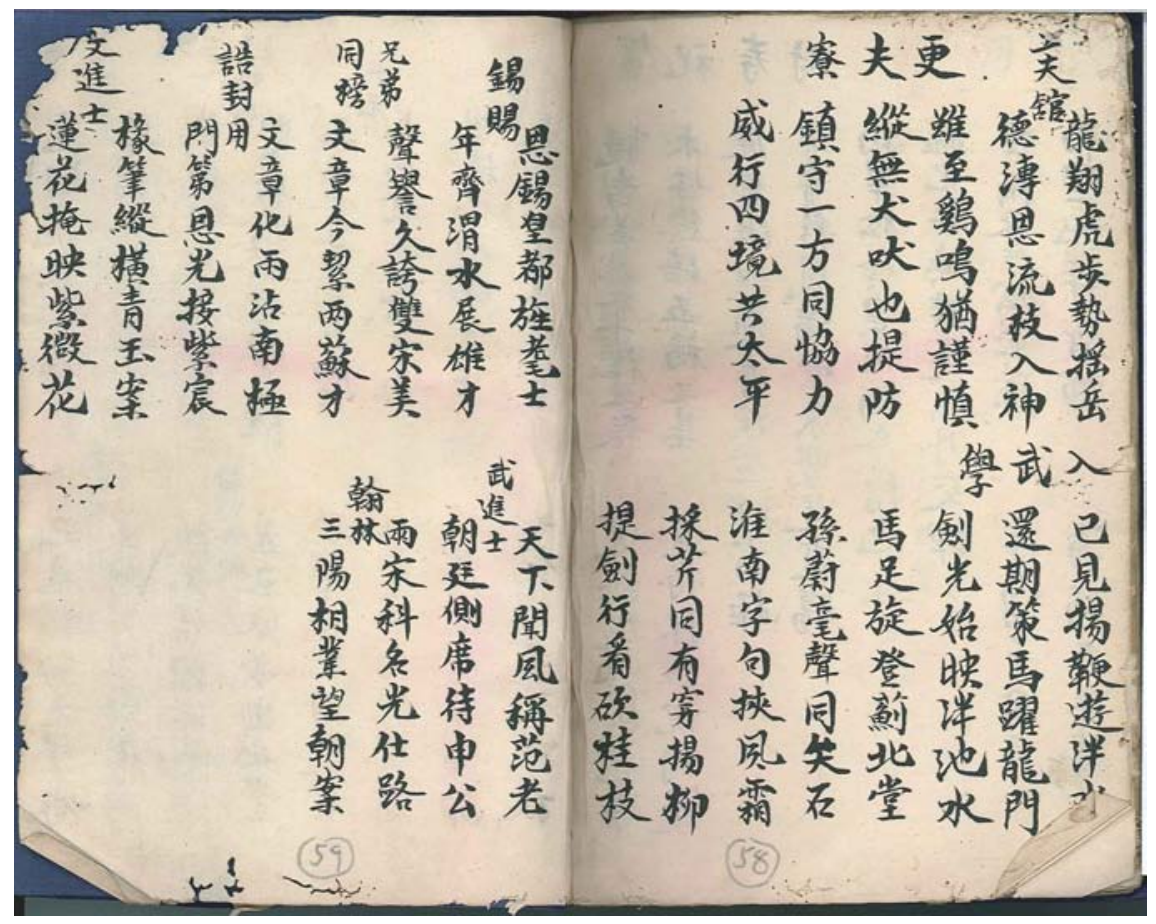

FIGURE 7.17

Mr. Qian's Notebook [Qian xiansheng zhi chaoben 錢先生之抄本], Pages 58 and 59, Scrolls to Honor Scholarly Accomplishments. Mr. Qian offered matching couplets to honor academic achievements. On page 58 , he listed many sample phrases for students who were beginning study to receive a military degree [Ru wuxue 入武學]. For those studying for various higher degrees or who were locally prominent, he had sample phrases such as "presented scholar" [jinshi 進士] degree on page 59 and on the extreme left of the page samples for a civil degree [wen jinshi 文進士] and, at the bottom of that page, for a military degree [wujin 武進] and for promotion to the Hanlin 翰林 Academy.

Рното BY AUTHOR

Empyrean [Yuanxiao 元宵] share the same name as the Lantern festival celebrated every January 15 on the lunar calendar. Mr. Qian prepared many sample texts for celebrating the Lantern festival [pp. 25-28, twenty-three examples]. He prepared couplets for the important Jade emperor (p. 29, two examples). Entrepreneurial Mr. Qian also had a large category of sample couplets to be

80; Zhao Shiyu, "Town and Country Representation as Seen in Temple Fairs," in Town and Country in China: Identify and Perception, ed. David Faure and Tao Tao Liu (Oxford: Palgrave, 2002), 49; Kenneth Dean, "Transformations of the She (Altars of the Soil) in Fujian," Cahiers d'Extrême-Asie, 10 (1998): 45. 


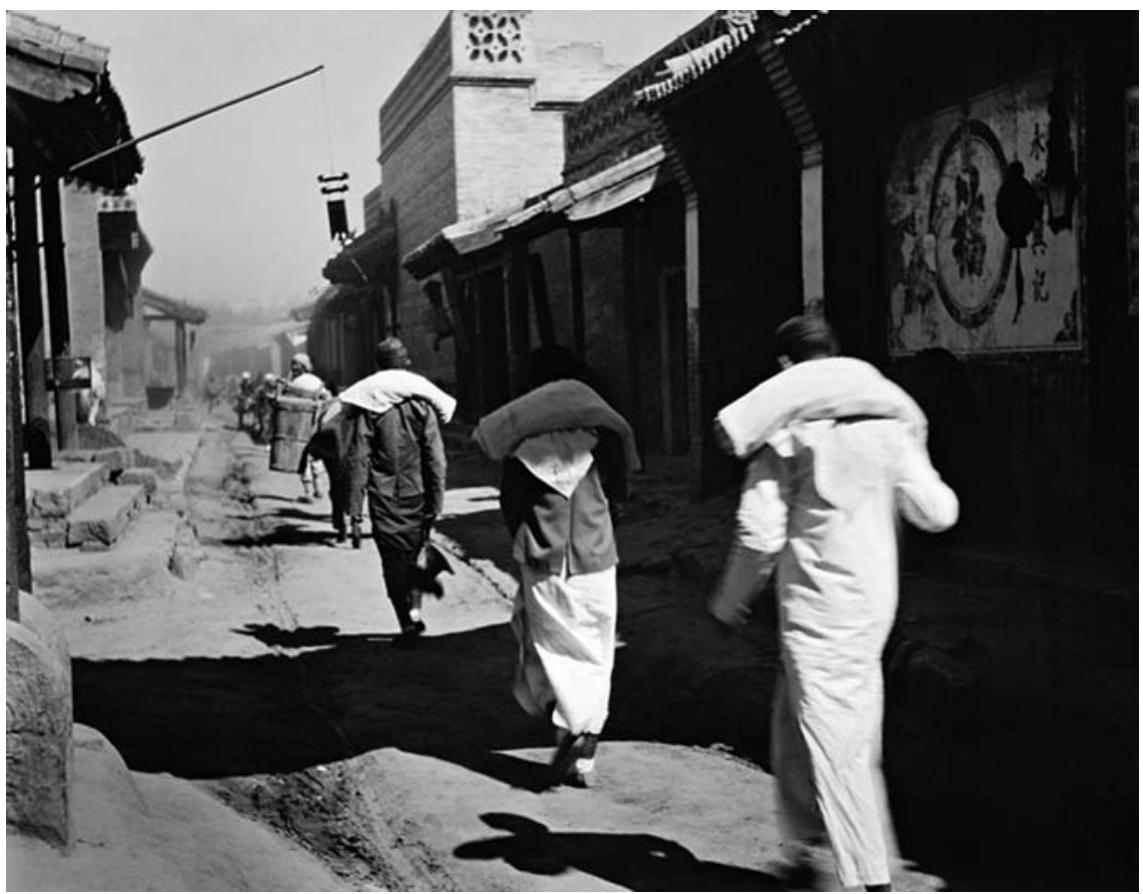

FIGURE 7.18

Merchant Runners Carrying Copper Cash. Shops in China needed cash for their transactions. Silver ingots [yinding 銀錠] were used for expensive transactions calculated in high denominations [liang 兩] while copper cash [qian 錢] was used for everyday transactions calculated in lower denominations. The photo shows people carrying money, called "runners" [benpaozhe 奔跑者, zousizhe 走私者], who work for a money-changer [piaohao 票號] or a pawnshop [dangpu當鋪]. The metal currency was heary, so they carried it on their shoulders. It also is early in the morning, which would have been the safest time for the runners to carry the cash.

PHOTO: CARRYING CASH, FENYANG 汾陽, SHANXI 山西, 1916; PHOTO: WILLIAM LEETE; RESTORATION AND PRINT (C2O15 WILLIAM MORSE. USED BY SPECIAL PERMISSION

used for any other deities who were honored [shenqian dui 神前對; pp. 19-21, twenty-four examples]. ${ }^{32}$

32 The Gods of the Empyrean is also the festival of the first of the Three Officials [Sanguan], who rule over the three periods of the year, so a visit to a local temple was also part of the celebrations for many people at that time of year. See Kenneth Dean, Taoist Ritual and Popular Cultures of South China (Princeton: Princeton University Press, 1993), 88-89. This first deity [Shangyuan 上元 or Tianguan 天官] rules from the first moon to the end of the sixth, according to Goodrich, Peking Paper Gods, 309. Note the similarity between these three deities and those of the Three Officials mentioned above. This has caused people to 
Perhaps the clearest indication of Mr. Qian's ability to interact with the highest social strata of his community, and his confidence in getting requests from the elite, is the number of sample couplets he prepared and categorized according to the social occasions at which they would be displayed. For example, students who had passed the county-level government exams to become xiucai, could choose from the category of "those now entering the academy grounds," literally written as those who could now wander near the pool on the grounds of a Confucian academy [youpan yong 㧳泮用; p. 56, four examples]. Those who received higher-level degrees after examinations taken in the capital might have been awarded a civil degree [wenxue 文學; p. 56, one example] or a military degree [wuxue 武學; p. 56, one example]. ${ }^{33}$ People might exchange gifts on these occasions and present a couplet from the category of "bestowing a gift" [xici 錫賜; p. 59, one example].

Candidates who passed one of the higher-level imperial examinations in the capital usually were offered a government appointment either there or in a provincial office. Names of successful candidates were announced on a list [bang 榜] posted in the capital. Mr. Qian had a category of couplets for "two brothers who had both passed the exam" [xiongdi tongbang 兄弟同榜;

conflate these two sets of deities, and today the Sanguan are sometimes interchangeably called the Sanyuan. See the basic explanation in Zhu, Zhongguo daojiao gongguan wenhua, 284-286. Conflation of the two is mentioned in Zhang, Daojiao shenxian xinyang, 242; Kubo, Dōkyō no kamizami, 158. A handwritten book of forty-seven pages in my collection is titled Repentances to the Supreme Three Primes to Forgive Sins [Taishang sanyuan youzuifachan 太上三元宥罪法懺], in three volumes. The text is $9^{3 / 4}$ in $(24.76 \mathrm{~cm}) \mathrm{h} \times$ $81 / 4$ in $(20.95 \mathrm{~cm}) \mathrm{w}$ and was purchased in Beijing in March 2009, though it originally came from Hengyang 衡陽 in Hunan. It is discussed in more detail in Chapter 8. This text contains the phrase "Tianzungyan zhengyue shiwuri, shangyuanguan 天尊言正月十五日, 上元官 [To Revered Heaven on the fifteenth day of the first month, [to the] Shangguan," 4. This shows the conflation in which the beginning of the first yuan [yuanxiao] on January 15 is also addressed to the First Yuanguan 上元官. Following the phrase is a list of thirteen honorary titles for this deity (pp. 4-6).

Kaiping was proud of the number of its residents who had attained a formal education and a government-issued degree. For example, in 1802 the country gazetteer recorded two juren [recommended scholars], seven gongsheng [holders of a purchased degree], four jiansheng [imperial academy scholars], one jinshi [presented scholar], and eleven shengyuan [licentiates]. In 1843 some fourteen men of educated status were recorded, including two wusheng 武生 [military degree] and a xiangbin 鄉賓 [local distinguished person]. For these examples, see Ming-Qing shike wenxian quanbian 明清石刻文獻全 編 [Complete Texts of Stone Inscriptions and Documents from the Ming and Qing]. Beijing: Beijing tushuguan chubanshe, series 5, 2: 2003, 684 and 688. 2003. A thorough discussion is in Elman, Civil Examinations and Meritocracy in Late Imperial China. 


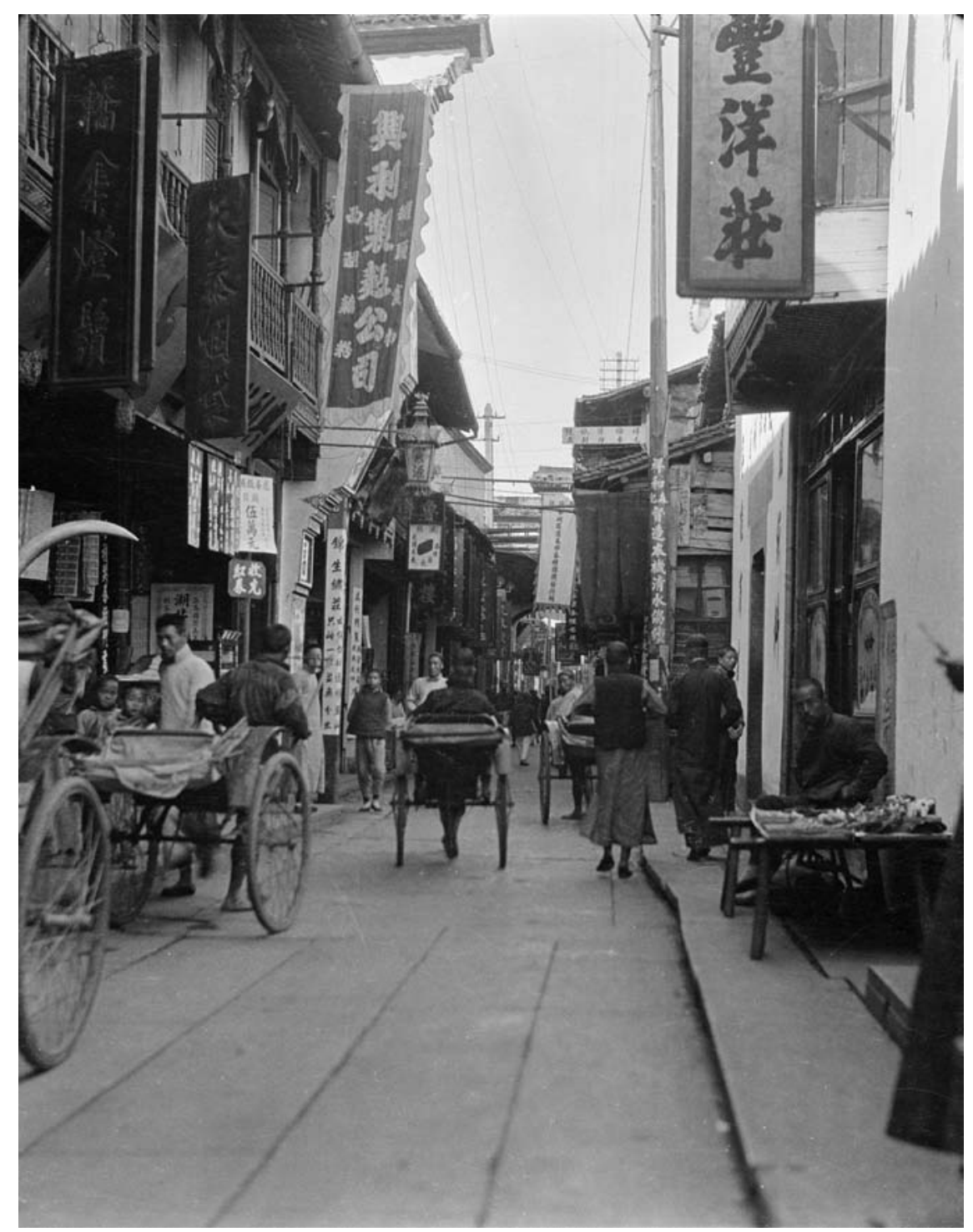

FIGURE 7.19

A Prosperous Commercial Street in South China. The photo shows a clean and orderly commercial street in Hangzhou 杭州, taken about 1919. The street is paved and has a lot of foot traffic as well as electricity. This street was most likely typical of the community in which Mr. Qian [Qian xiansheng 錢先生] earned a living by writing felicitous scrolls for individuals and merchants.

SIDNEY D. GAMBLE PHOTOGRAPHS, DAVID M. RUBENSTEIN RARE BOOK \& MANUSCRIPT LIBRARY, DUKE LIBRARY 
p. 59, one example]. The crème de la crème were candidates who were "first in the examination" [zhuangyuan 狀元; p. 6o, one example]. Candidates who placed second were also honored as "eye of the list" [bangyan 榜眼; p. 6o, one example]. Candidates who placed third were known as "selected talent" [tanhua 探花; p. 6o, one example]. All three were usually appointed to the prestigious Hanlin 翰林 Academy in Beijing. Some candidates "took the examination and upon investigation [of the results] were awarded a degree" [qianlie jianhou rupan 前列鑑後入泮; p. 6o, two examples]. Similarly, cases might occur in which an "elder brother is an academy scholar, and a younger brother is awarded a military degree” [xiong jiansheng diwuxue 兄鑑生弟武學, p. 6o, one example $].{ }^{34}$ Within the educated and official hierarchy, military degrees were considered somewhat second class, but among the general population they were respected as official recognition of achievement.

Degrees could be obtained by other means as well. The emperor might confer a degree conferred for “individual merit" [engong 恩貢; p. 61, one example]. A degree might be given in recognition of a "tribute [money or gifts] paid to the Imperial Court" [en nagong 恩納貢; p. 61, one example]. Western scholars refer to these as purchased degrees, in the sense that they were awarded after a "tribute payment," but the process was not automatic and purchasers first had to prove that they were qualified to become a member of the elite by dint of their own accomplishments or the status of their family, tracing back three generations. Some were awarded degrees because they were "especially sent by their prefecture to take the imperial examination" [ba gong 拔貢; p. 6o, one example]. Receiving an "appointment to the prestigious Hanlin Academy" in Beijing was sufficient reason for a congratulatory couplet (p. 59, one example). Some were appointed as "alternate [accessory] senior licentiate" [ fugong 副貢; p. 61, one example]. Mr. Qian was aware of all these categories and wanted to be prepared in case someone in this category of achievement approached him for a couplet. ${ }^{35}$

34 This was true not only in traditional China but Korea. The differences between the two sets of exams and their resultant career tracks are discussed in Eugene Y. Park, Between Dreams and Reality: The Military Examination in Late Choson Korea, 1600-1894 (Cambridge, MA: Harvard University Asia Center, 2007).

For comments on the status of a Hanlin scholar, see Kaizuka Shigeki 貝塚茂樹, Chūgoku no rekishi 中國の歷史 [Chinese History] (Tokyo: Iwanami shoten, 1994), 3: 9-10. On the status of a jinshi, see ibid., 2: 49-5o. A useful and thoughtful consideration of the examination system in China is Elman, A Cultural History of Civil Examinations in Late Imperial China. For broad coverage of the examination system with See also the useful glossary in Bastid, Educational Reform in Early Twentieth-Century China, appendix 3. 
The local elite in Kaiping county engaged in various courtesies, such as presenting a couplet to welcome a notable visitor [xiangbin 鄉賓; p. 6o, one example] or when an "honorary title was conferred by the emperor" [gaofeng $d u i$ 誥封對; p. 59, one example], or even when someone wished to present a couplet to "honor the prefectural governor." Evidently, his clientele included people with enough wealth and status to be on the list of those welcoming the government's chief representative in the province [he xunzhengting 賀巡政廳; p. 61, one example].

This section of Mr. Qian's notebook indicates that he was writing at a time when the Qing examination system and subsequent conferring of degrees according to that examination system were still in place. I estimate Mr. Qian was writing sometime in the late Qing dynasty, perhaps between 1880 and 1906. The absence of references in Mr. Qian's suggested couplets (as could be found in writings done during the Taiping rebellion) to civil unrest or the difficulties of military life indicates that he was writing after the Taiping rebellion had ended, post-188o. In 1905 the examination system, with its attendant awards and celebrations, was abolished, which ended the need for couplets celebrating degrees and honors associated with it. Thus we conclude Mr. Qian was writing while the Qing dynasty was still in power.

\section{Conclusion: What the Notebooks Reveal}

It is instructive to compare the notebook of Mr. Bai with that of Mr. Qian. The differences in the two manuscripts these men prepared throw into sharp relief their different communities and expectations. Both were working at a time (roughly between 188 o and 1913) when most of the traditional values and social practices sanctioned throughout the Qing, if not earlier, were still in place, and the custom of hanging matching couplets, or presenting them as gifts, was widely practiced. Both men thought they had enough formal education and literacy to earn income by providing matching scrolls to those who requested them, so they prepared a notebook of sample poetic texts, divided into categories based on where the scrolls would be hung or which occasion was commemorated. This was one fairly sure way for a literate man who had some formal education and some facility in calligraphy to earn income.

Because I bought Mr. Bai's book in Beijing, I assume he lived somewhere in North China or southern Manchuria. Mr. Bai's book was written on low-quality paper and bound with twisted paper twine. The writing inside was all over the pages, in margins and formerly blank spaces, as if on many occasions $\mathrm{Mr}$. 
Bai wanted to write down something quickly and chose the first empty space he could find on the page that was most convenient. The pages have distinct smudge marks where it appears someone repeatedly leafed through the book, those seem to have been heavily used. The calligraphy in his chaoben was acceptable, reflecting much practice. However, Mr. Bai often appeared unsure about how to correctly write some characters, so he wrote for his own reference many standard characters that a customer might request and likely assume he would know how to write. Occasionally he miswrote a character, which was then crossed out. Such extra characters or phrases appear on various pages throughout the notebook as notes to himself. These characters may have been intended for one of the horizontal papers that were sometimes hung above the two duilian or for a diamond-shaped piece of paper to be pasted on the gates.

Mr. Bai allowed others to write in his notebook. The calligraphy of several different people appears in this book: the two students who copied the story related to "Taigong Goes Fishing"; a scholar, possibly a friend or even Mr. Bai's former teacher, who wrote a couplet in elegant calligraphy; and the name of Jiang Wen probably written by a boy. It is possible that, even if the bulk of the text that I attribute to Mr. Bai was written by him, several of the occasional characters written as notes were later added by someone else. It is not always possible to identify how many writers were responsible for most of the text in this book or whether one person wrote most of it. I conclude that Mr. Bai wrote most of the basic text, including a number of standard poems in the beginning pages that I surmise he used to tutor his students, the story of Taigong, the sample couplets, and the marginal notes of additional characters and phrases.

But if I am mistaken, then Mr. Bai is actually a composite of one or two people who were responsible for this notebook. Even if that is the case, the materials represented in the notebook, the categories of couplets, and the status of the religious deities mentioned do reflect the limited expectations and the smaller community in which Mr. Bai, whether a composite or a single person, lived.

I posit that Mr. Bai's formal education at a traditional local academy/school was interrupted in 1905, when a new system of public schools modeled after the Western system of elementary, middle, and upper-middle schools, with a curriculum based on printed textbooks each covering a particular subject, such as mathematics, geography, or chemistry, was announced. The traditional local school curriculum, which was privately funded and in which subjects such as calligraphy, Confucian values, and the Classics formed the basis of the curriculum, did not disappear overnight but continued to operate in China, 
especially in rural areas, well into the 1930s. In many communities in China, some disruption occurred, as schools reorganized and began to insist on higher school fees to cover the cost of textbooks and the hiring of new teachers able to teach the new subjects. It is plausible that Mr. Bai was a victim of this disruption in his formal education, which might account for his need to write notes to himself on how to correctly compose a number of characters that he should otherwise have known. After 1905, the study of the core of classical texts was no longer a path to success in government-sponsored examinations that would allow someone to climb the ladder of education and status to attain appointment as a government official. The new system meant that to obtain a job as a government bureaucrat or as a schoolteacher, one needed to first graduate from elementary and higher school and then from a university or college. Government jobs were awarded upon success in civil service examinations or through one's network of personal contacts [guanxi 關係]. Many people were discouraged by this change in the system or did not have money for the new schools and decided not to enter them, possibly including Mr. Bai.

I assume that the categories of couplets Mr. Bai was prepared to offer, as shown in his notebook, reflect the major categories of people and religious sites in the community where he lived. Mr. Bai might have thought that his customers would most likely come from people who lived nearby, therefore from only a subset of his community. I believe that Mr. Bai lived in a small and fairly poor community in North China that lacked large religious temples and had few businesses. His decision to write the couplet announcing that Yuan Shikai was president and Li Yuanhong the military chief indicates that he lived in a small and possibly isolated community, in which the information on the couplet could be taken as news because the local people did not otherwise have recent news of major political events.

It appears that Mr. Bai's community included only a few people who had houses with both a front and rear gate. The few deities whose altars were in his community were generally folk gods or relatively minor deities in the Daoist pantheon, though they were popular, such as the kitchen god and the Dragon King of the Well. For example, larger urban centers likely had alters to honor the Emperor Guan [Guandi 關帝] or the city god [chenghuang 城隍], but it appears these deities did not have a worship site in Mr. Bai's community.

Among the other deities honored in Mr. Bai's community were the King of Horses, worshipped by those who transported goods; the fire god, who protected against disastrous fires; and the Buddhist Deity of Clear Sight, who was widely worshipped where trachoma was frequently found. Mr. Bai's community also worshiped the important Grandfather of Heaven and the Protector 
Against Demons [Zhongkuiye 鐘道爺]. These deities were often revered by the common people and their communities. ${ }^{36}$

Mr. Bai also earned income as a teacher or tutor for elementary school-age students. Like many people who preferred the old curriculum even after the new system of schools was put in place, he offered the traditional curriculum of classical poetry, morality tales, and calligraphy. His students, judging from the two pages on which they copied the commentary on the story he had taught them, "Taigong Goes Fishing," shows that they were young and still fairly inexperienced in writing with a brush, probably between the ages of eight and twelve, the common age of students in the beginning years of the traditional curriculum.

In sum, I conclude that Mr. Bai struggled with his own limited education to work as a teacher of young children and was prepared to offer congratulatory or celebratory couplets to the community as a way to earn extra income. His selection of the story of Taigong shows a degree of optimism in the idea that perseverance pays off, but his comments on the venal side of people shows that he was aware that the sincerity of all people cannot be accepted at face value. By teaching these stories to his students, he was trying to educate them for the broader adult world they would eventually enter, and at the same time he wanted them to accept some of his own values, in a cautious and measured way.

Mr. Qian's book offers a strong contrast to Mr. Bai's lack of confidence in his own abilities and to the poor and isolated community in which Mr. Bai lived. We know neither how Mr. Qian earned his income nor his station in life. Like Mr. Bai, he may have tutored students. He had neat though not outstanding calligraphy, the result of years of practice. He may have been a meticulous person who wanted to be ready for all eventualities, so he was prepared for a large quantity of requests for couplets from a wide variety of people. $\mathrm{He}$ apparently expected to some of those requesting couplets to be well-to-do,

${ }_{36}$ To be fair to Mr. Bai, as mentioned in the text it must be pointed out that Mr. Qian's community also had temples to many of the same popular folk deities as in Mr. Bai's community. In Daoist temples, the Buddhist Goddess of Mercy is often referred to as the Perfected Vessel of Compassion [Ziheng zhenren 茲航真人]. Mr. Bai did not provide sample texts for any Buddhist deities, which suggests that no established Buddhist temple was in his vicinity; rather, only smaller temples dedicated to the gods of popular religion. This indicates a rural area or a community inhabited exclusively by pingmin. Mr. Qian used the standard appellation Guanyin for sample couplets in his chaoben (p. 24, seven examples). See Zhang, Daojiao shenxian xinyang, 551-553; Goodrich, Peking Paper Gods, 158-16o. 
living in large compounds with inner courtyards. The social occasions for which they might require couplets also showed that Mr. Qian's contacts were at the highest levels of his local society, including those who had passed their imperial examination and received an appointment to high office. The paper on which Mr. Qian wrote his sample couplets had been bleached white, indicating a more expensive grade, and it was bound with cotton string.

The categories of business in Mr. Qian's locality indicate that his was a thriving, moderate to large community with some manufacturing (of farm implements and liquor). The degree of commercial activity was sufficient for at least one silver casting shop. His community had altars dedicated to the major deities of Daoism (such as the Jade emperor), Buddhism, and the folk god accepted by both Daoists and Buddhists, Mazu (媽祖), the Holy Mother Queen of Heaven. The major deities honored in these temples were popular in South China, and they often had many lesser deities housed with them, so each of these temples might have been substantial and composed of several buildings. Mr. Qian expected to receive business from those temples. If $\mathrm{Mr}$. Qian lived in Kaiping County in Guangdong, where the bookseller told me this notebook had originated, then he lived in a thriving community, bolstered by agriculture and trade. The extent of comfortable courtyard homes and $\mathrm{Mr}$. Qian's awareness of the active religious life of his community are indicated by the sample couplets he prepared for display on an open veranda in a gentry home and for the community altar, where many community members regularly gathered.

The sample couplets that Mr. Qian prepared reveal the extent of the community where he lived and the level of social interaction that he enjoyed. Mr. Qian, like Mr. Bai, would be expected to be asked for couplets to celebrate the New Year [xinchun 新春], or weddings [xinhun 新婚] or birthday celebrations of an elder's longevity [zhushou 祝壽], so we should not be surprised to find many example couplets in these categories. Every community had people who wanted couplets to honor an ancestor [zhuzu 祝祖], or to announce mourning for a death [sangjia 喪家], and even Mr. Bai expected to receive orders for those kinds of duilian. Mr. Qian, however, lived in a community of greater social complexity, whose needs for the proper expression of social transitions through written couplets exceeded those in Mr. Bai's small village, as the wider categories of sample couplets attest.

Mr. Qian's community had a prominent and active elite, and he was wellconnected enough that he might expect to be asked to provide a couplet for those occasions. He was known to people who celebrated their son's passing a government exam or receiving a higher degree or appointment to the prestigious Hanlin Academy in Beijing. He was aware of people who received their 
degree through paying tribute to the emperor or through special consideration by the emperor. Some men being "awarded an imperial title" might need a couplet to celebrate that honor, and Mr. Qian had an example ready. He even expected to be asked to provide a couplet to welcome the visit of the provincial governor. The people who requested these duilian would have been from the most well-heeled strata of the community, most likely either landed gentry or large merchants. Mr. Qian must have assumed that some people in that social strata would approach him to write a couplet on their behalf and had appropriate samples ready.

To summarize, these two handwritten notebooks have striking contrasts. They indicate that Mr. Bai was not well practiced in his calligraphy or in his ability to recall the important characters he needed to know in order to correctly write the matching couplets that would be requested of him. Being a bit sloppy or disorganized in his approach to life, he copied down those characters whenever he ran across an example in which they were written correctly. His local community in North China was small and isolated and was composed of a limited range of economic strata and few businesses. Mr. Bai must have struggled to earn a good living by trading on his status as a literate man who had some degree of formal education.

I characterize Mr. Qian as a confident and organized person who must have been pleased with his neat and practiced calligraphy. His community seems to have boasted a number of economic and social elite families, and Mr. Qian had access to those families. The many such families who lived in large compounds with several gates, the range of local businesses, and even the larger temples in town all seemed likely to approach him for matching couplets on important occasions.

When we, as scholars and readers, encounter handwritten materials such as the two chaoben discussed here, we need to read into the text and consider the implications of the written material and its presentation. If we can date the book or place it in a geographic area, we need to reconstruct the social and economic environment in which it was prepared. It is equally intriguing and fun to hazard a reconstruction of the circumstances of the person who wrote the material, to understand why he decided to compile the notebook, how he used the book in daily life, and the major social and cultural values that influenced his understanding of the material and its role, and indeed his own role in the community where he lived. I have attempted to do this for the two manuscripts discussed in this chapter. At each point, I have identified an aspect of interest and have suggested a logical interpretation of it that seems to be supported by the written material or by our current understanding of the likely place and times in which the book was used by living human beings. It 
is possible that I am mistaken on some points or many points in this analysis, but on each point I have made a logical and informed guess that should be consistent with all the other analytical guesses and assumptions in this chapter. The result is a story of two men who shared cultural values and lived at roughly the same time yet lived in two rather different communities and whose own expectations and opportunities were quite dissimilar.

Collections of texts for duilian were ubiquitous in China in the late Qing period. Printed texts of sample couplets are readily available in Chinese-language bookstores today. Almanacs widely sold during the New Year festival usually contain a selection of suggested couplets. These might be considered "mass-produced" couplets or general couplets suitable for use by a wide range of people. It appears that most contemporary Chinese do not observe as many social occasions needing a couplet nor do they carefully classify family occasions strictly by familial relationships. Rather, the greatest use of matching couplets nowadays is to celebrate the New Year, followed by weddings, at which couplets in red are a big part of the decorations. Almanacs contain samples of couplets for birthdays to honor an elder, as well as for funerals, when the couplets appear on white paper in place of the celebratory red paper.

In traditional China, the use of matching couplets on hanging scrolls was common. I have found that in the handwritten notebooks I have acquired dating from the late Qing and early Republican era, many include lists of sample couplets, usually divided into broad categories. I have seen them in notebooks otherwise containing religious information, sample letters, or sample contract forms. The two examples of notebooks focusing on couplets considered in this chapter are not unique in that sense. Being able to write elegantly with a brush a pair of hanging scrolls with a matching couplet was a sure way for a literate and educated person to earn some income as much as it was, indeed, one of the signifying marks of literacy.

At present, the antiques and flea markets in China offer a variety of old chaoben. However, very few scholars in or outside China use these materials as a way of uncovering the lives of ordinary people. Almost no libraries collect them but, like the stereopticon slides of the Victorian era, they can give us an intriguing and somewhat three-dimensional, multifocused view of China's pingmin culture in the late nineteenth and early twentieth century. 